\title{
How Santa Claus Became a Slave Driver: The Work of Print Culture in a Nineteenth-Century Musical Controversy
}

\author{
DOUGLAS W. SHADLE
}

\begin{abstract}
The transnational character of the literate musical community in the United States created an environment in which language barriers, ideological biases, and other potential sources of misunderstanding caused print items to change shape quickly as they were transferred from one reader to the next. The aesthetic controversy between William Henry Fry and Richard Storrs Willis surrounding the 1853 premiere of Fry's Santa Claus: Christmas Symphony provides a rich case in point. The controversy at times seemed to draw from a parallel debate in Europe, often called "The War of the Romantics," which concerned the future of symphonic composition and music's capacity for representation. At others, the controversy seemed to diverge from its European counterpart as central concepts were articulated in new intellectual contexts. The vagaries of print culture help explain these discrepancies. This article outlines the central arguments of the debate, situates them within their transatlantic contexts, and examines how print culture played a significant role in the controversy's unfolding as early as 1839, fifteen years before it took place. More broadly, it constructs a new framework for examining the function and meaning of nineteenth-century music periodicals by illustrating how an antislavery newspaper became an unlikely voice in a debate over program music.
\end{abstract}

The vibrant global and national print cultures of the nineteenth century brought people together in unlikely ways. On 26 May 1855, readers of the New York Evening Post, a Free Soil daily, were greeted with an uncharacteristic front-page headline: "Another Grand Symphony! Cheering from the South!" Like most urban dailies, the Evening Post printed occasional reviews of musical performances, though rarely as the lead story. The country was in the throes of an increasingly hostile conflict over slavery, after all, and a new symphony was hardly the day's most pressing concern. Newsboys probably lost their voices trying to hawk it. As readers found out, this was no ordinary review-and no ordinary piece of music.

According to the notice, a German immigrant composer named Herr Treiberneger (to be translated as "Nigger-driver," we learn) had premiered his long-awaited "Plantation Symphony" for a Richmond audience featuring a host of proslavery luminaries, including Abraham Lincoln's future nemesis Stephen Douglas. Amid sounds of the audience's tobacco spitting, the epic symphony vividly portrayed the brutal beating, harrowing escape, and return to enslavement of Anthony Burns, an actual runaway slave whose controversial Boston trial and eventual removal to

I would like to thank Katherine Preston, Glenda Goodman, William Gibbons, Marie Sumner Lott, Travis Stimeling, and Laurie McManus for reading earlier versions of this article and offering valuable insights; the anonymous peer reviewers, whose detailed comments helped me clarify my argument and the overall presentation; Steven Gerber for graciously providing scans of the holograph manuscript of Fry's Day in the Country; and the Library Company of Philadelphia for awarding me a short-term research fellowship to examine Fry's other manuscripts. 
Virginia had made national headlines just a year earlier. ${ }^{1}$ In the work's final moments, the audience joined the orchestra in a rousing rendition of "Hail Columbia, Happy Land," a triumphant gesture turning the meaning of the choral finale in Beethoven's Ninth on its head. The concert was an unqualified success.

This grisly review (reprinted in the appendix) was a satirical fabrication intended to illustrate the absurdity of slaveholders and their political supporters. Perhaps more notably, it also makes subtle, clever, and at times obscure references to the culture of classical music in the United States at mid-century. ${ }^{2}$ Specific pieces by Haydn and Beethoven, two of the most beloved composers at the time, serve as points of comparison with the symphony, and the author casually mentions a Herr Löstiswitz, a fictional composer of "descriptive" instrumental music whose story had appeared widely in print a year earlier. ${ }^{3}$ Beyond these minor details, the significant choice of a descriptive symphony as a medium of political satire is left without remark. For readers today, such an unusually rich piece of musical fiction seems oddly out of place in a daily newspaper, but it would have made sense to mid-century readers who kept abreast of musical news-and it likely would have been profoundly moving.

The review, I argue, was one of the last traces of a furious and protracted journalistic debate between composer William Henry Fry (1813-64) and critic Richard Storrs Willis (1819-1900), both of New York, that had erupted after the local premiere of Fry's Santa Claus: Christmas Symphony in December 1853. The debate continued to unfold during the months leading up to Anthony Burns's fugitive slave trial the following May. This spirited feud is remembered primarily for Fry's frontal assault on the New York Philharmonic Society's routine neglect of music written by U.S. composers, despite a clause in its by-laws stipulating otherwise. ${ }^{4}$ For two months, however, the debate also centered on two thorny aesthetic issues: instrumental music's capacity for representation and the symphony's future as a viable compositional medium.

Using Santa Claus as case in point, Fry challenged commonly held conceptions of the nature of the symphony, arguing that its form should follow a dramatic literary narrative rather than a conventional schema or plot, and that representational

\footnotetext{
${ }^{1}$ The notoriety of Burns's escape and trial can hardly be overstated. Contemporaneous accounts include The Boston Slave Riot, and Trial of Anthony Burns (Boston: William V. Spencer, 1854); James Freeman Clarke, The Rendition of Anthony Burns: Its Causes and Consequences (Boston: Crosby, Nichols, \& Co., and Prentiss and Sawyer, 1854); and Charles Emery Stevens, Anthony Burns: A History (Boston: John P. Jewett and Co., 1856). The case has been analyzed more recently in Albert J. Von Frank, The Trials of Anthony Burns: Freedom and Slavery in Emerson's Boston (Cambridge, MA: Harvard University Press, 1998) and Earl M. Maltz, Fugitive Slave on Trial: The Anthony Burns Case and Abolitionist Outrage (Lawrence: University of Kansas Press, 2010), 55-160.

${ }^{2}$ The odd remarks about musical technique suggest, however, that the author was not a practicing musician.

${ }^{3}$ The word "descriptive" was in common use for music intended to represent external objects; the word "programmatic" had not yet been coined.

${ }^{4}$ The most thorough scholarly accounts of the debate are Vera Brodsky Lawrence, Strong on Music: The New York Music Scene in the Days of George Templeton Strong, 3 vols. (Chicago: University of Chicago Press, 1995-99 [1988]), II:479-89; and Katherine K. Preston, "American Orchestral Music at the Middle of the Nineteenth Century," in Symphony No. 2 in D Minor, Op. 24 ("Jullien"), by George Frederick Bristow, ed. Katherine K. Preston (Middleton, WI: A-R Editions, 2011), lxxv-lxxvii.
} 
musical gestures should point listeners toward deeper philosophical meanings. Indeed, he distributed a printed synopsis at performances so that listeners could follow its story. ${ }^{5}$ Willis, on other hand, held that a symphony-and music more generally—should tend toward abstraction and remain in standardized, traditional forms. The debate's thousands of readers had never witnessed such a vehement and abstruse dispute concerning music aesthetics. And by all accounts, Fry's audiences enjoyed the music despite the feud: Santa Claus was persistently encored.

From today's vantage, this "musical battle of the century" (as one scholar has called it) appears to be a residual spinoff of the primarily German aesthetic imbroglio often labeled the "War of the Romantics." Claus controversy were indeed the very concerns of the so-called Zukunftsmusiker, or "Musicians of the Future," such as Richard Wagner and Franz Liszt, and an opposing "conservative" faction that included critics Ludwig Bischoff (1794-1867) of Köln and Eduard Hanslick (1825-1904) of Vienna. Wagner and Liszt, like Fry, argued in favor of new musical forms and a unification of the arts, whereas Bischoff and Hanslick, like Willis, argued for adherence to convention and music's aesthetic independence. ${ }^{7}$ Beyond these philosophical links, which placed Fry and Willis close to the cutting edge of aesthetic thought on a transatlantic scale, both manifestations of the conflict shared specific metaphorical imagery. But there is one significant problem: the Santa Claus debate did not arise from a one-way flow of information from Europe. Hanslick's incendiary and pivotal Vom Musikalisch-Schönen ("On the Musically Beautiful") was not published until September 1854, several months after the debate's conclusion. The "war" was still developing in Europe as Fry and Willis were in full swing.

How a seemingly Europe-centered conflict came to include an asynchronous American counterpart that in turn spawned a bizarre antislavery satire-that is, how Santa Claus became a slave driver-is an intriguing mystery. The key to solving it is its very condition of possibility: a vibrant transatlantic print culture, with all of its messy, slow, and unpredictable twists and turns. Print materials did not follow straight paths. They moved, were read, changed shape as they were processed and discussed, and moved again, much like today's children's party game Telephone. ${ }^{8}$ Innocent whispers could easily morph Tannhäuser into Treiberneger.

The game that concerns us here took full shape following the 1848-49 revolutions in the German-speaking lands, when the transatlantic networks of

\footnotetext{
${ }^{5}$ This synopsis is reprinted in William Treat Upton, William Henry Fry: American Journalist and Composer-Critic (New York: Thomas Crowell Co., 1954), 335-38.

${ }^{6}$ See Lawrence, Strong on Music, II:378; and Alan Walker, Franz Liszt: The Weimar Years, 1848-1861 (New York: Alfred A. Knopf, 1988), 338-67.

${ }^{7}$ The most concise account of this conflict is James Deaville, "The Controversy Surrounding Liszt's Conception of Programme Music," in Nineteenth-Century Music: Selected Proceedings of the Tenth International Conference, ed. Jim Samson and Bennett Zon (Aldershot, Hants, UK: Ashgate, 2002), 98-124. Bischoff, the least prominent figure mentioned here, was editor of the Rheinische Musik-Zeitung and later the Niederrheinische Musik-Zeitung, on his career, see Robert Lee Curtis, Ludwig Bischoff: A Mid-Nineteenth-Century Music Critic (Köln: A. Volk, 1979).

${ }^{8}$ For an exploration of this process, see Bob Nicholson, "'You Kick the Bucket; We Do the Rest!': Jokes and the Culture of Reprinting in the Transatlantic Press," Journal of Victorian Culture 17 (2012): 273-86.
} 
German-language and English-language musical information exchange began to intersect more widely, creating a space in which monolingual Anglophone readers became increasingly dependent on non-Anglophones while constructing knowledge about the musical world. ${ }^{9}$ Balances of power and knowledge fluctuated constantly between continental Germans, American visitors abroad, U.S. residents who could read one or more languages, and even the British. Using the Santa Claus controversy as an outwardly radiating focal point, this essay illuminates the ways in which information exchange networks could serve as tools for knowledge construction and allowed print to perform its cultural work during the nineteenth century.

\section{The Prism of Mid-Century Print Culture}

Print materials such as newspapers and magazines - to say nothing of booksserved as vital vehicles of national and transatlantic information exchange throughout the nineteenth century, particularly during the American antebellum era. Cultural theorists and historians have long argued for the importance of such exchange in the construction of broad public spheres that unify disparate individuals into local and national communities. ${ }^{10}$ These spheres were of course international as well. From the colonial era onward, British North America (and later the United States) occupied a western node within economic and information networks that crisscrossed the Atlantic, and the region's musical culture participated directly in these networks. ${ }^{11}$ Although London served as a leading nexus for over a century, the eastern ends of the networks expanded during the period between 1800 and 1850 as the British metropolis lost its cachet—at least in minds of many Americans—as the center of the European musical world. Educated elites and upper-middle-class audiences on the eastern seaboard developed a greater appreciation for German music and aesthetic thought during the period; the significant influx of German musicians into the country during and after the 1848-49 revolutions augmented this intellectual shift. ${ }^{12}$

\footnotetext{
${ }^{9}$ This type of space has been called a "contact zone," defined as a "social spaces where cultures meet, clash, and grapple with each other, often in contexts of highly asymmetrical relations of power." Mary Louise Pratt, Imperial Eyes: Travel Writing and Transculturation, 2nd ed. (New York: Routledge, 2008), 7-9.

${ }^{10}$ Classic studies include Benedict Anderson, Imagined Communities: Reflections on the Origin and Spread of Nationalism, rev. ed. (London: Verso, 2006); and Jürgen Habermas, The Structural Transformation of the Public Sphere, trans. Thomas Burger and Frederick Lawrence (Cambridge, MA: MIT Press, 1989). Targeted case studies concerning the American reading public include Michael Warner, The Letters of the Republic: Publication and the Public Sphere in Eighteenth-Century America (Cambridge, MA: Harvard University Press, 1990); and David M. Henkin, City Reading: Written Words and Public Spaces in New York (New York: Columbia University Press, 1998). For a similar approach outside the United States, see William Garrett Acree, Jr., Everyday Reading: Print Culture and Collective Identity in Rio de la Plata, 1780-1910 (Nashville, TN: Vanderbilt University Press, 2011).

${ }^{11}$ On the importance of British networks on musical life in colonial America and in the early Republic, see Michael Broyles, "Music of the Highest Class": Elitism and Populism in Antebellum Boston (New Haven, CT: Yale University Press, 1992), 7-14; Glenda Goodman, "Musical Sleuthing in Early America: 'Derry Down' and the XYZ Affair," Common-place 13/2 (Winter 2013): http:// www.common-place.org/vol-13/no-02/goodman/; and Nicholas Temperley, Bound for America: Three British Composers (Urbana: University of Illinois Press, 2003), 1-11.

${ }^{12}$ See Broyles, "Music of the Highest Class", 198-268; Nancy Newman, Good Music for a Free People: The Germania Musical Society in Nineteenth-Century America (Rochester, NY: University of Rochester
} 
German-speaking musicians in turn developed new patterns of transatlantic economic exchange and enjoyed freedoms in the United States that had been limited in German-speaking lands. ${ }^{13}$ The prominent Hamburg music publisher Julius Schuberth, for example, established a New York branch of his business in 1850 , which dramatically increased the availability of current music and writing published in Germany. Bookshops with in-house presses such as B. Westermann and Co. in New York (a subsidiary of the Braunschweig-based Georg Westermann) and Schäfer and Koradi in Philadelphia, both of which opened in 1848, eventually became foreign subscription and distribution agents for European music periodicals such as the Neue Zeitschrift für Musik (hereafter NZfM). ${ }^{14}$ And German-language newspaper editors could print without fear of censorship or political retribution. ${ }^{15}$ Beyond the well-documented appeal of the United States as a source of commercial profits for foreign performers, the country also became an important marketplace for the exchange of goods and ideas related to music, despite its geographically peripheral location relative to the central powers of Europe.

The growth of a German-language print culture in the United States had residual effects on Anglophone print culture as well. Among native English speakers, editors comprised a significant percentage of the core readership of foreign music journals. ${ }^{16}$ The more access they had, the more access they could grant their readers. It is all the more remarkable, then, that the aesthetic split in 1854 between Fry and Willis, both of whom were periodical editors, tended to fall along the precise factional lines that were forming at virtually the same moment in the Germanspeaking world, creating a "shared present." Thousands of American readers were quickly thrust into the European musical present-or at least some version of itand encountered a debate that was taking shape on the other side of the Atlantic, largely outside of their knowledge. ${ }^{17}$

The structure of journals created a potential disjuncture between the information-gathering capacity of subscribers and the repositories of information erected by journal editors on their exchange desks. Music periodicals in the United States, England, and the German-speaking lands typically shared the same general

Press, 2010), 7-15; and Frédéric Louis Ritter, Music in America (New York: Charles Scribner's Sons, 1883), 371-84.

${ }^{13}$ See Robert Cazden, A Social History of the German Book Trade in America to the Civil War (Columbia, SC: Camden House, 1984), 159-79. These changes in print culture eventually influenced the international status of the United States before and during the Civil War; see Andre Fleche, The Revolution of 1861: The American Civil War in the Age of Nationalist Conflict (Chapel Hill: University of North Carolina Press, 2012).

${ }^{14}$ See Cazden, A Social History, 193-96; John Hruschka, How Books Came to America: The Rise of the American Book Trade (University Park, PA: Penn State University Press, 2012), 70-109; and Lawrence, Strong on Music, II:199.

${ }^{15}$ At around this time, the daily New-Yorker Staats-Zeitung also began to feature a section, usually written by Schuberth himself, called "Kleine Musikzeitung" (among other headings).

${ }^{16}$ Editorial offices were able to send their issues to other editorial offices via the postal service (and international equivalents) at no charge; this benefit explains the widespread practice of reprinting other articles. See David M. Henkin, The Postal Age: The Emergence of Modern Communications in Nineteenth-Century America (Chicago: University of Chicago Press, 2006), 42-62, and Eli Bowen, The United States Post-Office Guide (New York: D. Appleton and Co., 1851), 42-43.

${ }^{17}$ The notion of a "shared present" created by news streams and information transmission pervades Brendan Dooley, ed., The Dissemination of News and the Emergence of Contemporaneity (Surrey, UK: Ashgate, 2010). 
approach to content. Each issue would contain, in varying combinations, extended editorials, excerpts or reprints taken from other periodicals or publications, criticism of pieces and performances, news or "gossip" about musical activities (often gleaned from other periodicals), and local, national, or foreign correspondence. Three of these items - reprints, gossip, and correspondence-were entirely dependent on information exchange networks such as the Postal Service (or the shipping industry more generally) and shaped public opinion about musical life in other regions the most strongly. ${ }^{18}$

As clearinghouses of information, editorial offices actively managed perceptions about other places around the region and the globe. Deciding what to reprint or have translated, for example, gave editors an extraordinary amount of power over public perception. ${ }^{19}$ It was an open question as to whether translations were faithful, sources reliable (when revealed at all), or reprints complete and accurate. And given that false news stories could spread like wildfire-Mark Twain's infamous "death" among them—casual readers of music periodicals likely had no reason to assume bad faith on the part of an editor. ${ }^{20}$ In a sense, editors were gatekeepers of current events, and bilingual writers such as Willis (German) and Fry (French) held disproportionately large amounts of control within the information network. Following the lead of editors and writers, readers' perceptions of other individuals and cultures were then filtered through their own sets of biases in a process that created a prismatic truth when reading - much more so than in earlier eras when American print culture was primarily monolingual.

One direct example of such refraction occurred around the time of the Santa Claus debate. In spring 1853, a few months before the work's premiere, Boston editor and critic John Sullivan Dwight (1813-93) sent several issues of his new eponymous journal, along with a listing of music performed in Boston during the 1852-53 concert season, to the editorial office of the NZfM. His goal was to illustrate Boston's musical catholicity, and thus to impress the leading journal in the German musical world. A lengthy open letter to Dwight, penned by the avid Wagner supporter Richard Pohl (1826-96), appeared a few weeks later in the NZfM. ${ }^{21}$ Duly

\footnotetext{
${ }^{18}$ The value of these transmissions for readers is evident in the collection and republication of Lowell Mason's letters from Europe; see Lowell Mason, Musical Letters from Abroad: Including Detailed Accounts of the Birmingham, Norwich, and Dusseldorf Musical Festivals of 1852 (New York: Mason Brothers, 1854). Students studying in Germany were also a valuable source of information about European musical life, and a handful of them sent occasional missives to journal editors; see $\mathrm{E}$. Douglas Bomberger, "The German Musical Training of American Students, 1850-1900" (Ph.D. diss., University of Maryland at College Park, 1991).

${ }^{19}$ For an extensive illustration of this notion in the French press, see Katharine Ellis, Music Criticism in Nineteenth-Century France: La Revue Gazette et Musicale (Cambridge: Cambridge University Press, 1995), 33-55.

${ }^{20}$ On music periodical readers and general periodical reading practices in the United States, respectively, see Mary Veronica Davison, "American Music Periodicals, 1853-1899" (Ph.D. diss., University of Minnesota, 1973), 199-200; and Barbara Sicherman, "Ideologies and Practices of Reading," in A History of the Book in America, Volume 3: The Industrial Book, 1840-1880, ed. Scott E. Casper, Jeffrey D. Groves, Stephen W. Nissenbaum, and Michael Winship (Chapel Hill: University of North Carolina Press, 2007), 285-88.

${ }^{21}$ Hoplit [Richard Pohl], "Ein Blick nach dem 'fernen Westen'. Offenes Sendschreiben an Mr. J. S. Dwight," NZfM 39 (1853): 269-73.
} 
impressed, Pohl interpreted the information from Dwight as proof that the United States was ready to become the new home of Wagner's music. Having acquired a taste for the modern music in such a short time, he claimed, the country had already surpassed most of Europe in its musical advancement. Using a characteristically Hegelian expression reminiscent of the American doctrine of Manifest Destiny, he closed the letter by exclaiming, "Westward moves the history of art!" Dwight read, translated faithfully, and reprinted the article alongside his own coy commentary, which cautioned Pohl to curb his enthusiasm: even Wagner would need to win the approval of the American public to earn a place alongside the classics, just like any other aspiring composer. ${ }^{22}$ Pohl viewed the United States as fertile ground for Wagnerism, whereas Dwight saw it as a bastion of reserved classicism.

These two perceptions of American musical life on the ground, generated exclusively by print exchanges, continued to refract during the Santa Claus furor. As the conflict grew, Fry and his fellow composer George Frederick Bristow (1825-98) shifted the discussion to the Philharmonic's neglect of Bristow's music while each accused the organization of being an instrument of German colonization. ${ }^{23}$ Near the tail end of the conflict, a German-speaking U.S. reader dispatched a lengthy letter to the staunchly anti-Wagnerian Niederrheinische Musik-Zeitung, headquartered in Köln and edited by Ludwig Bischoff, one of Wagner and Liszt's key antagonists. The missive, signed with the mysterious moniker "Dr. F.," described the Santa conflict and the general musical climate in the United States using terms that were clearly favorable to the journal's conservative agenda:

The [Philharmonic] Society has its opponents in the public, especially among patriots, because, according to its by-laws, it performs compositions only of an already well-established reputation (and thus primarily by first-rate Germans, though Berlioz's King Lear overture was the first concession to the new Romantic School), and because it consequently does not open the gates of its inner sanctum to American composers. ${ }^{24}$

Then, after describing the decision of visiting French conductor Louis Antoine Jullien (1812-60) to perform American works such as Santa Claus as a savvy business maneuver designed to capitalize on this nativist sentiment, Dr. F. commented further on the music itself: ${ }^{25}$

22 “A Greeting from Germany," Dwight's Journal of Music (hereafter DJM), 30 July 1853, 132-34.

${ }^{23}$ They actually used the word "Hessian," a bitter invocation of the nation's collective memory of 30,000 German troops, mostly from the region of Hesse, hired to support the British Army during the Revolutionary War. Fry, "Music. Concert of the Philharmonic Society," New-York Daily Tribune (hereafter NYDT), 7 March 1854; Bristow: "The Philharmonic Society," Musical World \& Times (hereafter $M W \mho T$ ), 4 March 1854, 100.

24 "Die Gesellschaft hat im Publicum, besonders unter den Patrioten, auch ihre Gegner, weil sie statutmässig nur Compositionen von bereits anerkanntem Rufe, also vorzüglich deutsche aufführtBerlioz's Lear-Ouverture war die erste Concession an die neu-romantische Schule-, und weil sie eben desshalb den americanischen Componisten nicht die Pforten ihres Heiligthumes öffnet." Dr. F., "Musicalische Zustände in den Vereinigten Staaten von Nordamerica," Niederrheinische Musik-Zeitung für Kunstfreunde und Künstler 2 (1854): 116. Dr. F. neglected to mention that the Philharmonic's bylaws also required the organization to support local composers. Unless otherwise noted, all translations are mine.

${ }^{25}$ The authoritative account of Jullien's tour in the United States is Katherine K. Preston, "'A Concentration of Talent on Our Musical Horizon': The 1853-54 Tour by Jullien's Extraordinary 
Fry has ideas and imagination but does not understand how to extend and develop his thoughts thematically, or how to handle form properly. He follows the false path of representational, painterly music. His Santa Claus symphony is an unfortunate effort, entirely formless, full of reminiscences, and without unity of idea and style. The second, The Breaking Heart, shows improvement and has details that suggest creative talent. ${ }^{26}$

Dr. F.'s report differed significantly from Dwight's. Terms such as "formlos" and the criticism of "der darstellenden, malenden Music" as a "false path" would have suggested to Bischoff's readers that Fry-as one of only two significant American composers - was already spreading Wagnerism among Americans, whereas Dwight seemed to say that Wagnerism would have to wait its turn. ${ }^{27}$ German readers were receiving mixed messages.

Within a matter of months, at least four substantially different perspectives on the general state of musical life in the United States took shape in widely distributed periodicals: Dwight's conservative musical agenda, Fry and Bristow's complaints about cliquish German musicians, Pohl's belief in Americans' readiness for Wagnerism, and Dr. F.'s warnings about Wagnerian encroachments. By filtering information through ideological prisms, each side saw what it wanted to see, interpreted the concrete situation quite differently, and communicated "facts" to subscribers; readers of more than one journal or newspaper were left to sort out "truth" for themselves. Anthony Burns, the former slave, was living in Boston, far away from the ruckus, but was only days from being captured by slave catchers.

\section{Staging the Santa Claus Conflict by Reading about Schumann}

Old Saint Nick had no idea he was entering such a free-for-all when he flew into New York City on Christmas Eve, 1853. That night, Jullien and his virtuosic orchestra premiered Fry's Santa Claus. ${ }^{28}$ Despite the audience's enthusiastic applause-silenced only by a full encore-certain reviewers frowned on this evocative work because

Orchestra," in American Orchestras in the Nineteenth Century, ed. John Spitzer (Chicago: University of Chicago Press, 2012), 319-47.

26 "Fry hat Ideen und Phantasie, aber er versteht weder seine Gedanken thematisch fortzuspinnen und durchzuführen, noch die Form gehörig zu handhaben. Dabei ist er auf dem falschen Wege der darstellenden, malenden Musik; seine Sinfonie 'Santa Clauss' ist ein unglücklicher Versuch, ganz formlos, voll Reminiscenzen, ohne Einheit der Idee und des Stils. Die zweite, 'Das gebrochene Herz', zeigt einen Fortschritt und hat Einzelheiten, welche von schaffendem Talente zeugen.” Dr. F., "Musicalische Zustände," 116.

${ }^{27}$ Dr. F. commented on Bristow's symphonies, which follow conventional models, using only slightly more favorable terms: "Bristow works more rigorously, knows and respects the laws of form, and orchestrates well, but his invention is flat. [Bristow arbeitet gründlicher, er kennt und achtet die Gesetze der Form und instrumentirt gut; aber seine Erfindung ist matt.]" An editor for still another New York journal, incidentally, undermined Fry and Bristow by responding directly to Dr. F.'s article and asking Bischoff editor to send more German musicians to the United States: "They and we will work together in the cause we have most at heart-the advancement of music," the editor wrote. "Musical Gossip at Home and Abroad," New York Musical Review and Choral Advocate (hereafter NYMRCA), 11 May 1854, 157.

${ }^{28}$ The complete score for this work is available in Sam Dennison and Martha Furman Schleifer, eds., Three Centuries of American Music: A Collection of Sacred and Secular Music, vol. 9, American Orchestral Music, 1800 through 1879, ed. Sam Dennison (Boston: G. K. Hall and Co., 1992), 229-321, and it has been recorded, along with three of Fry's other orchestral works, on William Henry Fry, Santa Claus Symphony, Naxos 8.559057. 
it lacked the gravitas of a true symphony. A snubbed and infuriated Fry, believing the piece was indeed an "earnest work of art," launched a calculated offensive that occupied the New York musical press for the next four months and drew several important figures into its vortex. His primary sparring partner was Willis, editor of the weekly Musical World and Times, but the debate also came to include, among others, Dwight, Bristow, and the Beethoven biographer Alexander Wheelock Thayer (1817-97). Was Santa Claus truly a symphony? That was the driving question, at least for now.

The vast majority of the controversy's readers were not aware that a similar conflict had been bubbling in Europe among the German musical intelligentsia following Beethoven's death. ${ }^{29}$ The period from 1849 to 1855 was particularly contentious, and the conflict would fan outward over the next several decades. ${ }^{30}$ Although the symphony as a genre was not the flashpoint of these mid-century aesthetic debates, questions about its nature and future occupied a central place. Richard Wagner and Franz Liszt both theorized modes of musical expression that they hoped would supersede the conventional four-movement symphony: the music drama and Programmusik, respectively. ${ }^{31}$

Fry occupied a space on the aesthetic spectrum near Wagner and Liszt. All of his "symphonies" were representational in nature, not abstract, and their form followed a delineated literary narrative. They were, in essence, program music. The timing of Fry's symphonies and the debate surrounding them thus seems especially noteworthy. The term "symphonic poem" had not appeared publicly, even in Europe, yet the evocative titles, descriptive synopses, poetic or dramatic inspiration, and even the condensed, single-movement structures of Fry's symphonies suggest a manifestly similar approach to Liszt's. ${ }^{32}$ Like Liszt and a handful of others, Fry, it seems, was attempting to determine the future of the symphony by breaking traditional molds. It is therefore possible to situate the aesthetic portion of the Santa Claus debate, and Fry's symphonies, within these ongoing contemporary discourses, which became refracted through print culture.

The symphony as a genre was in flux at mid-century. Standard scholarly accounts of its nineteenth-century development in German-speaking lands can be

${ }^{29}$ In the United States, the rare foray into aesthetics in the years following Beethoven's death typically appeared as commentary on the value of instrumental music versus vocal music. See, for example, [H. Theodore Hach,] "Beethoven Symphonies," The Musical Magazine 3 (24 April 1842): 392-97.

${ }^{30}$ See Mark Evan Bonds, Absolute Music: The History of An Idea (New York: Oxford University Press, 2014), 129-249.

${ }^{31}$ See Richard Wagner, Das Kunstwerk der Zukunft, in Gesammelte Schriften und Dichtungen, 4th ed., 10 vols. (Leipzig: C. F. W. Siegel, 1907), III:115-16. See also Franz Liszt, "Berlioz und seine Haroldsymphonie," Neue Zeitschrift für Musik 43 (1855): 42, and 81. It is now known that Liszt was aided by Princess Caroline zu Sayn-Wittgenstein; her authorial role is explained in Detlef Altenburg, "Vom poetisch Schönen: Franz Liszts Auseinandersetzung mit der Musikästhetik Eduard Hanslicks," in Ars Musica,Musica Scientia: Festschrift Heinrich Hüschen zum fünfundsechzigsten Geburtstag am 2 März 1980, ed. Altenburg (Köln: Gitarre und Laute, 1980), 4-5.

32 Walker, Franz Liszt, 304. Several scholars have suggested that these works are really symphonic poems (or "tone poems"), not symphonies at all. See Gilbert Chase, America's Music: From the Pilgrims to the Present, rev. 3rd ed. (Urbana: University of Illinois Press, 1987), 306; Preston, "American Orchestral Music," lxvi; and Upton, William Henry Fry, 317. 
summarized neatly: even while Beethoven was alive, his symphonies were widely recognized as groundbreaking and superior exemplars of a general ideal type; this greatness cast a long shadow over aspiring symphonic composers and precipitated a gradual lull beginning in roughly 1830 and that reached a nadir in the 1850s; and a new generation of composers revitalized the genre after 1860 , especially in the quarter century following the premiere of Brahms's First. ${ }^{33}$ Certain composers determined to produce sufficiently individual and original works-Berlioz, Mendelssohn, Schumann, Brahms, and Mahler-willfully “misread" Beethoven's symphonies, especially the Third, Fifth, and Ninth, by confronting five central problems: form, the role of text and voice, the fusion of genres, unity and cyclic coherence, and the role of the finale. ${ }^{34}$ Composers such as Félicien David and Ludwig Spohr wrote similarly experimental works prior to the pivotal decade of the 1850s, whereas others, including many of those named above, continued to follow the well-established models of Haydn, Mozart, and Beethoven, or else avoided the symphony altogether. ${ }^{35}$

Robert Schumann contributed significantly to the construction of the standard narrative, suggesting that our contemporary understanding of the genre's development aligns somewhat closely with that of his initial readership. Schumann's reviews of other symphonies written during his tenure as editor of the NZfM, for example, reveal that he was supremely concerned with navigating the narrow path between showing respect to Beethoven's authority and carving out new territory — what has been called the "imperative of originality." 36 Fry shared this precise concern, and it is perhaps most ironic that he judged Schumann's own Second Symphony by the same critical standard in a review of the work's New York premiere. In order to use this typical critical trope in his writings, Fry had to have come into contact with European discourse concerning the symphony. By 1853 , there was virtually no critical tradition surrounding the assessment of new works, especially symphonies, in the United States.

Schumann, in Fry's opinion, paled in comparison to Beethoven's greatness. "We hold it to be an inflexible rule in the philosophy of Art," he began,

that it must assume new forms, or if old ones are adhered to, they should be improved upon in the spirit of the works bearing such an antique construction. Without joining in the attacks made in London on Schumann, (as is done with every new man) we cannot think that he has improved on Beethoven in the classic Symphony, but that his works are inferior to that master. We cannot discover the same plainness of statement or breadth of

\footnotetext{
${ }^{33}$ For detailed accounts of this narrative, see Mark Evan Bonds, "Symphony, II: 19th Century," Grove Music Online, ed. Deane Root http://www.grovemusic.com/; Walter Frisch, Brahms: The Four Symphonies (New York: Schirmer, 1996), 1-12; and James Hepokoski, "Beethoven Reception: The Symphonic Tradition," in The Cambridge History of Nineteenth-Century Music, ed. Jim Samson (Cambridge: Cambridge University Press, 2002), 424-59.

${ }^{34}$ The limits of musical description and narrativity in the Sixth Symphony could easily be added to this list. See Mark Evan Bonds, After Beethoven: Imperatives of Originality in the Symphony (Cambridge, MA: Harvard University Press, 1996), 20-21.

${ }^{35}$ During and after the 1850 s, questions about national identity and poetic content increasingly colored the genre's development beyond the five central issues named above; see Hepokoski, "Beethoven Reception," 430-47.

${ }^{36}$ See Bonds, After Beethoven, 24-27 and 111-17.
} 
treatment that Beethoven exhibits, independently of the difference of mind which of course each composer must manifest. We think, therefore, Mr. Schumann's symphony writing in the classic mold, a sheer waste of powder-if his desire was to excel Beethoven in that department, for he has not done so. ${ }^{37}$

This scathing critique, which borders on blasé dismissal, may have borrowed the interpretive paradigm developed by Schumann himself, but it diverged substantially from the generally high praise the symphony had received in the German-speaking world, where many critics also remarked on its resemblance to Beethoven's Fifth but considered this trait a point in its favor. And whereas Fry referenced contemporary controversies in London surrounding Schumann's music, which had been brewing since the previous year (and revealed Fry's reading interests), Schumann's English critics tended to associate him with the more progressive stream of composition that included Wagner and Berlioz-the precise opposite of Fry's perspective. ${ }^{38}$

As a budding symphonic composer, Fry wanted his review to accomplish goals that were ultimately different from those of Schumann's European critics. Schumann, he claimed, had failed to follow the imperative of originality facing all symphonic composers, but his other sins were of a particular kind:

If his wish was simply to write a symphony, in preëstablished traces, he has done so, showing
due acquaintance with the rhetoric of music and the machinery of an orchestra. [ . . ] There
is a great deal of mosaic detail in Schumann. If the piece had been descriptive (which we
think all music should be, dramatically,) we might be able to say more about it, than we can
now, as it was simply symphonic — without, any definite idea-beyond symmetry, rhetoric,
light and shade, and classic forms. ${ }^{99}$

Moving beyond the limits of the four-movement symphony was not Fry's only concern. From the opening of his review, he established his credentials as an aesthetic radical for whom even the most well-established models could pose no significant challenge to originality. Building on this position, Fry added that representational music - or "descriptive music," as he called it—would be the symphony's only forward path. These concepts were practically unknown to general American readers, as nothing quite like them had previously appeared in the mainstream musical press. ${ }^{40}$ By focusing specifically on breaking classical molds and pushing the limits

37 "Music. Concert of the Philharmonic Society," NYDT, 16 January 1854. A more forgiving but equally disappointed Willis used the same critical strategy a few days later, comparing the work unfavorably to Beethoven and Mendelssohn. See "Musical News from Everywhere. New York," MWঊT, 21 January 1854, 27.

${ }^{38}$ On Schumann's German reception, see Anthony Newcomb, “Once More 'Between Absolute and Program Music': Schumann’s Second Symphony,” 19th-Century Music 7 (1984): 234-36. On his London reception, see Janet Ritterman, "Schumann and the English Critics: A Study in NineteenthCentury Musical Reception," in Musical Dimensions: A Festschrift for Doreen Bridges, ed. Martin Comte (North Melbourne: Australian Scholarly Publishing, 2009), 194-98.

39 "Music. Concert of the Philharmonic Society," NYDT, 16 January 1854.

${ }^{40}$ It is worth noting, then, that Fry chose the phrases "simply symphonic" to describe the piece, not "absolute music," even though that is the concept he was clearly intending to evoke. By 1854, the phrase "absolute music" had not yet come to denote a specific type of repertory or musical content. The term was at that time merely an ill-defined aesthetic opposite of Wagner's Gesamtkunstwerk, or possibly any work not serving as an agent of historical development. Musical content was not yet part of the discourse. See Sanna Pederson, "Defining the Term 'Absolute Music' Historically," Music \& Letters 90 (2009): 244-45. 
of descriptive music, the kind of aesthetic "progress" that Fry wished to disseminate among his readers bore deep marks of contemporary European musical discourse, but readers probably had no idea about its possible origin.

\section{Reading the Conflict: Santa Claus on Trial}

That Fry was engaging with discourses beyond American shores is evident in his review of Schumann's Second. His knowledge of contemporary European musical aesthetics was even more apparent in the Santa Claus controversy itself. He had spent the previous six years in Paris as a correspondent for newspapers in Philadelphia and New York and occasionally drew on these experiences while debating. What made the conflict especially compelling, however, was the fact that readers were also able to witness and benefit from the informational storehouse of Richard Storrs Willis, who had a distinct intellectual heritage with differing connections to Europe. Following his graduation from Yale in the early 1840s, he also spent six years on the Continent, where he studied with Xaver Schnyder von Wartensee and Moritz Hauptmann. ${ }^{41}$ General readers unfamiliar with European musical life of the 1840 s and the day's current print culture-that is, most of them-would have greeted each side of the debate on its own terms, as if these were fresh ideas. The whole affair was rife with opportunities for misinterpretation among the participants and readers alike.

The debate itself focused on the very handful of issues that contemporary scholars have identified as central components within mid-century European aesthetic discourse-just as we saw in Fry's review of Schumann's Second. Fry's bold opening salvo, for instance, directly concerned both form and content: "I believe that Santa Claus is the longest instrumental composition on a single subject, with unbroken continuity" - the complete reverse of what critic Charles Burkhardt had dubbed a mere "pièce d'occasion" and that Willis had likewise considered "a good Christmas piece: but hardly a composition to be gravely criticized like an earnest work of Art." ${ }^{\prime 2}$ Both sides would present sophisticated arguments, but they did not use the terminology developed in the debate's German-language counterpart that is more familiar today since much of it had not yet been coined. The four central themes addressed in the controversy were: form and unity, musical representation, the roles of the voice and the finale, and the nature of the symphony as a genre. ${ }^{43}$

\section{Form and Unity}

All of Fry's symphonies were written in what is essentially a one-movement form, although he explained that two of them, including Santa Claus, unfold without

\footnotetext{
${ }^{41}$ On Willis's European education, see “Death of Mr. Chickering,” MWঊT, 17 December 1853, 121.

42 "A Letter from Mr. Fry," 29; Charles Burkhardt, "Music. Jullien’s Concerts: Mr. Fry’s New Symphony," The Albion, 31 December 1853, 632; and Willis, "Musical News from Everywhere. New York," MW\&T, 7 January 1853, 6.

${ }^{43}$ The sub-sections that follow address four articles by Fry and Willis appearing in the MW\&T: "A Letter from Mr. Fry" (21 January 1854); "Reply to Mr. Fry of the Tribune" (28 January 1854); "Rejoinder from Mr. Fry" (18 February 1854); and "Reply to Mr. Fry of the Tribune, Number II" (25 February 1854). They are always presented in this order.
} 
interruption over several distinct but musically connected sections-a schema stemming from his belief that unity follows from "the situations and progress of the plot, not in the number of the acts [or symphonic movements]." Using Beethoven's "Eroica" as a negative example, Fry argued that individual movements within a four-movement symphony might possess internal unity (especially those based on sonata-allegro form and employing motivic development), but that the standard progression of movements exhibits no intra-movement unity. This lack of unity, he suggested, would prohibit audiences from constructing an overarching narrative plot across the entire symphony. ${ }^{44}$

Willis responded that "there may be literary unity in the story which you connect in your own mind with the music [...] But there is no musical unity." Musical unity, or "coherence" as he also called it, has nothing to do with a story, but with "design, the attribute of reason." Music constantly in motion, shifting from one scene to the next, exhibits no reasoned pattern of organization, Willis contended, whereas thematic recurrence and motivic development retain a listener's interest. Here Willis presumed that a listener could apprehend the ways in which a piece of music might create a uniquely musical argument. Fry's aesthetic relied instead on a mutually reinforcing unification of the literary and the musical arts. By invoking the concept of "the specifically musical," then, Willis had merged his abstract conception of form with his preference for non-representation.

\section{Musical Representation}

"In the dreary ignorance of what is music," Fry bemoaned, "imitative music' is called the lowest kind. But all music is imitative, or it is good for nothing." He explained that music can imitate passion and emotion, natural elements or other sounds, scenes that have their own characteristic music (e.g., a funeral or a coronation), and the "mystic" movement of dreams, which he illustrated with unusual modulations and melodic figures. Fry's positive account of imitation reveals that he believed in music's ability both to transform non-musical objects into higher poetic objects and to disclose higher truths to listeners. And throughout his initial letter, he contrasted imitative music with "mere" mathematics. Slavishly following rules and formulas amounted to nothing more than writing the multiplication tables by rote. Music is not "mathematical intricacies," Fry insisted.

Willis again contradicted Fry at every turn, even calling his statement about imitative music "nonsense." Reframing the issue, he noted that imitative music was inherently unoriginal, since the represented object by necessity preceded its musical representation. Then, countering Fry's assertion about music's ability to disclose, he added that music can only suggest ideas, not express them, claiming that it "is a perfectly independent language: not a whit an imitative language." This independence was a function of its ability to transcend language - to begin where language ends. Finally, spitting on Fry, Willis concluded, "Making music imitative

${ }^{44}$ Fry's works, by contrast, exhibit a unity of design built first and foremost upon the written narrative plot, which is then underscored and enhanced, as necessary, by "classical" patterns of thematic return, tonal modulation, or contrast. He even provided an example in his first letter to Willis. The strategy of illustrating "Classical" credentials in experimental works was also used by European progressives; see Deaville, “The Controversy surrounding Liszt's Programme Music,” 103. 
is materializing and demeaning music. It is making a parrot of that which is a nightingale- a wretched tone-slave of what is a glorious tone-master." Fry quickly backed away from his statement that music could express abstract ideas, ${ }^{45}$ but it is clear that he believed music's essence was nevertheless grounded partly in the human voice, and thus in the material world, not in a wordless transcendental plane. ${ }^{46}$

\section{The Roles of the Voice and the Finale}

Fry's instrumental music is intensely lyrical. Rooted in a preference for cantabile melodies and highlighted solo instruments, his general approach to instrumental writing appears to be influenced heavily by opera, not the Germanic symphonic repertory that was quickly coalescing into canonical status in the United States. ${ }^{47}$ These vocal qualities were not lost on listeners. Reviewers singled out cantabile or soloistic passages, such as the "magnificent execution of a horn quartet, representing the Hymen [sic] of nature" (Example 1) and "the description of a snowstorm, with a traveler perishing [a lyrical double bass solo]," which was "excellently realized." 48 A detailed review of Childe Harold (1854), a symphony that premiered after the debate's conclusion, revealed similarly "vocal" moments: "Very soon out of the arid desert of feeling, ascends a minor melody, played on the Saxophone by WuiLLE, as the impersonation of the Childe or Knight Harold of the middle ages." ${ }^{49}$ Nothing, however, captured the essence of Fry's music better than Burkhardt's response to Santa Claus: "Its style and formation are not of the high school of art; they are of a modern Italian or French pattern, devoid of the severe but effective simplicity of Mozart or Beethoven. The Solo, Duo, and Trio parts for instruments, appear like Donizetti-ish vocal parts." ${ }^{50}$ (See Example 2.)

Beyond the cantabile and at times operatic nature of Fry's melodies, his works also exhibit deep engagement with instrumental music's capacity to emulate

\footnotetext{
${ }^{45}$ Liszt would later theorize a more robust rebuttal to a position such as Willis's with his "program music" concept.

${ }^{46}$ Focusing on the prevalence of the word "imitation" in Fry's writings, one writer has interpreted this retraction as a retreat into older theories of mimesis, in which music's capacity to represent external objects is limited to the imitation of natural sounds or verbal expressions. Although mimesis certainly plays a role here, the looseness of Fry's terminology and the music's non-literal mode of representation suggest that the term "imitation" was instead a convenient, not a bygone, choice. See Günter Leypoldt, Cultural Authority in the Age of Whitman: A Transatlantic Perspective (Edinburgh: Edinburgh University Press, 2009), 158n23.

${ }^{47}$ The Italianate melodies and ornaments in both examples, coupled with the occasional fermata or "colla parte" instruction, are his most obvious borrowings from opera; Fry had also written his own operas in the bel canto style.

48 "The Eleventh and Final Lecture of W. H. Fry," NYDT, 11 February 1853; and "Amusements. Jullien's Concerts," New-York Times, 29 December 1853. For more on the lectures, see Vera Brodsky Lawrence, "William Henry Fry's Messianic Yearnings: The Eleven Lectures, 1852-53," American Music 7 (1989): 382-411.

49 "Fry's New Symphony," NYMRCA, 8 June 1854, 201. Henri Wuille (1822-71) was a clarinetist in Jullien's orchestra who became an early advocate of the saxophone as a solo instrument; Fry capitalized on this unique opportunity. See Thomas Liley, "Invention and Development," in The Cambridge Companion to the Saxophone, ed. Richard Ingham (Cambridge: Cambridge University Press, 1998), 13.

50 "Music," Albion, 31 December 1853, 632.
} 

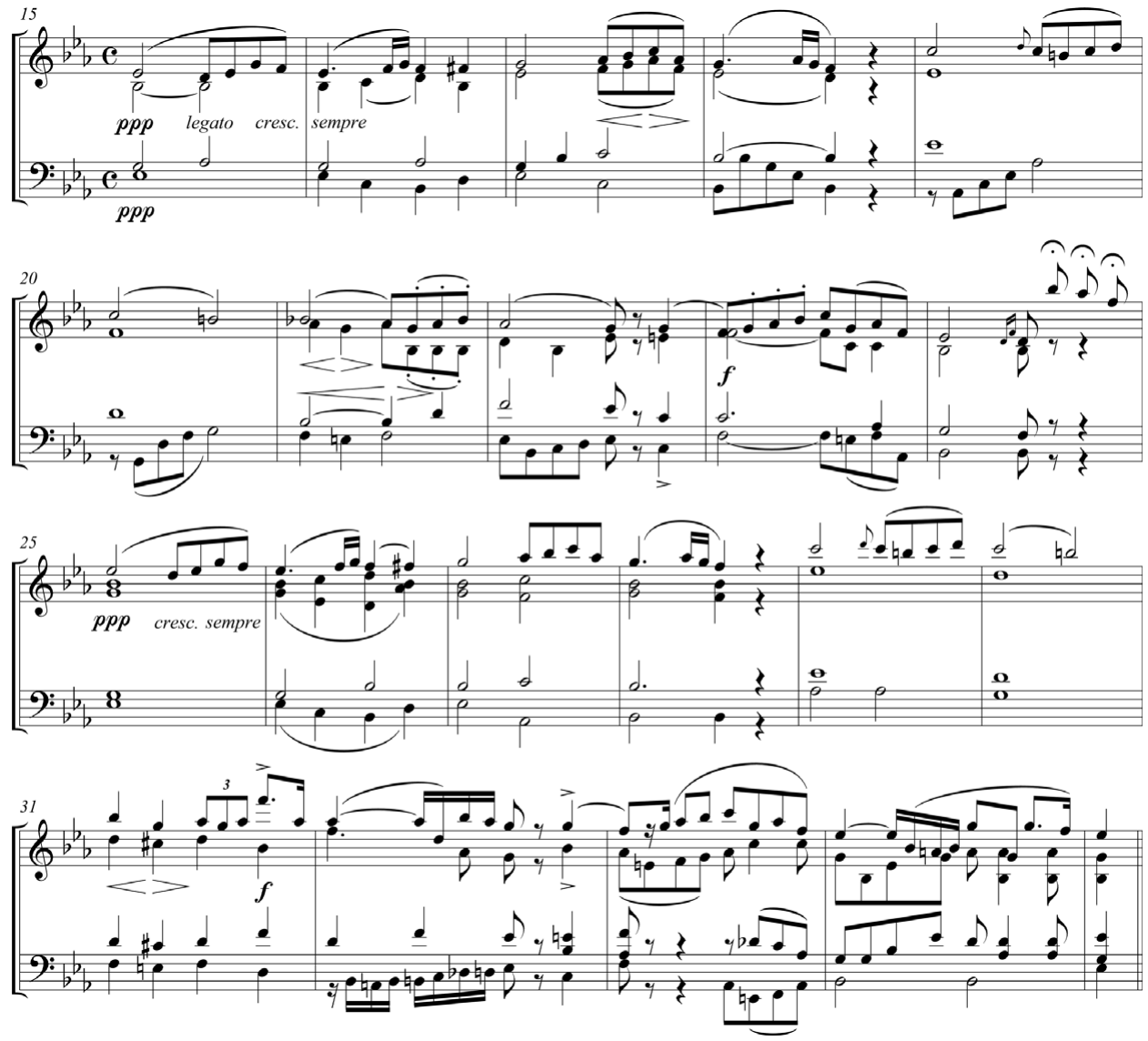

Example 1. Horn quartet: "Hymn to Nature." A Day in the Country, mm. 15-35. Theodore Thomas Collection, Rosenthal Archives, Chicago Symphony Orchestra.
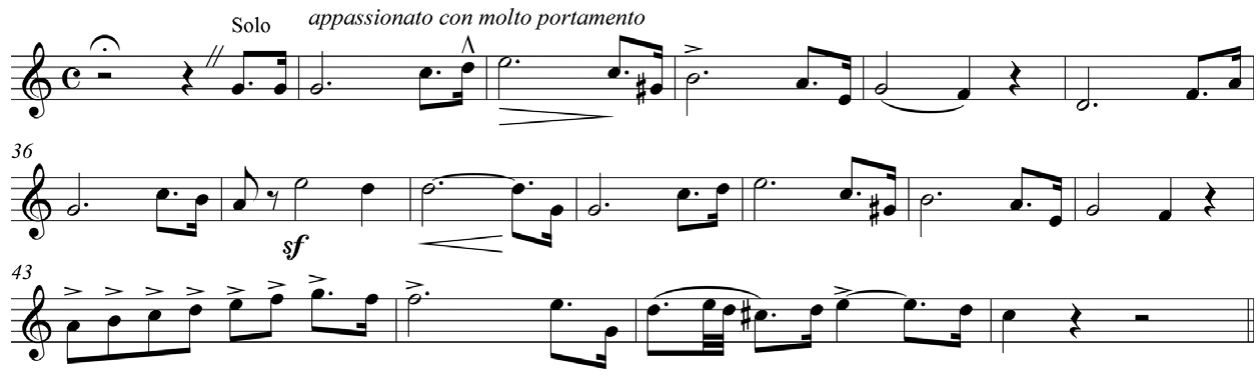

Example 2. Cantabile cornet solo. William Henry Fry, Santo Claus: Christmas Symphony, I, mm. 30-46 (Rehearsal A). William Henry Fry Collection, Library Company of Philadelphia.

vocal sounds, especially recitative. Roughly halfway through Santa Claus, the upper strings mimic, with instrumental recitative, the common English translation of the Pater noster, or "Our Father" (Example 3). For Fry, this particular stylistic choice was essential to the meaning of the work: the prayer was set to music, he argued, "not with the drawl of monks a la Palestrina or the frizzle of eunuchs a 
Un poco meno lento (quasi recit.)
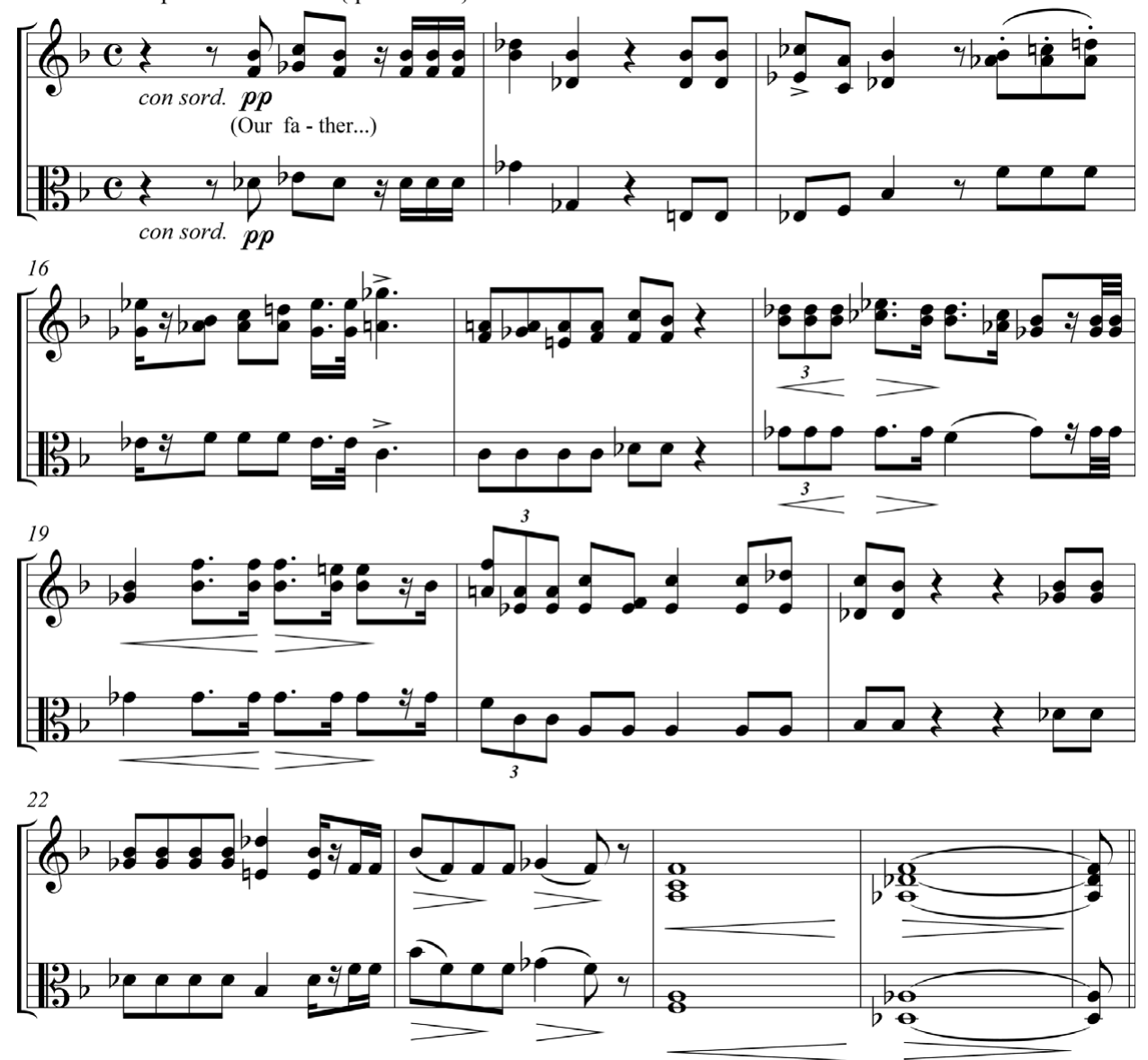

Example 3. Instrumental Recitative of "The Lord's Prayer." William Henry Fry, Santo Claus: Christmas Symphony, III, mm. 13-26 (Rehearsal L). William Henry Fry Collection, Library Company of Philadelphia.

la Farinelli, but according to the colloquial accents and purity of innocence and love." Despite praising it in his initial review, Willis sniped in his response to Fry that music imitating the tones of the voice would be "monotonous," mere talking and nothing more. Neither this passage nor the innovative idea of instrumental recitative resurfaced in the debate.

Perhaps more surprising, the stunning finale of Santa Claus also never surfaced in the discussion beyond Fry's initial description: the music "winds up with the Christmas hymn [Adeste fideles] instrumented with all the fullness of which only a great modern orchestra is susceptible, fortified by a chorus, and twelve drums,the latter to express the sublimity of the rolling spheres, echoing the glad tidings." This brief commentary offers only a glimpse into how the finale actually unfolds. As the printed synopsis explains, the Santa Claus melody (played by the bassoon) dies away and is replaced by an evanescent entrance of tremolo strings playing the hymn Adeste fideles (Example 4). This moment corresponds in character to the quiet entrance of the An die Freude melody, played by the low strings, in Beethoven's Ninth 

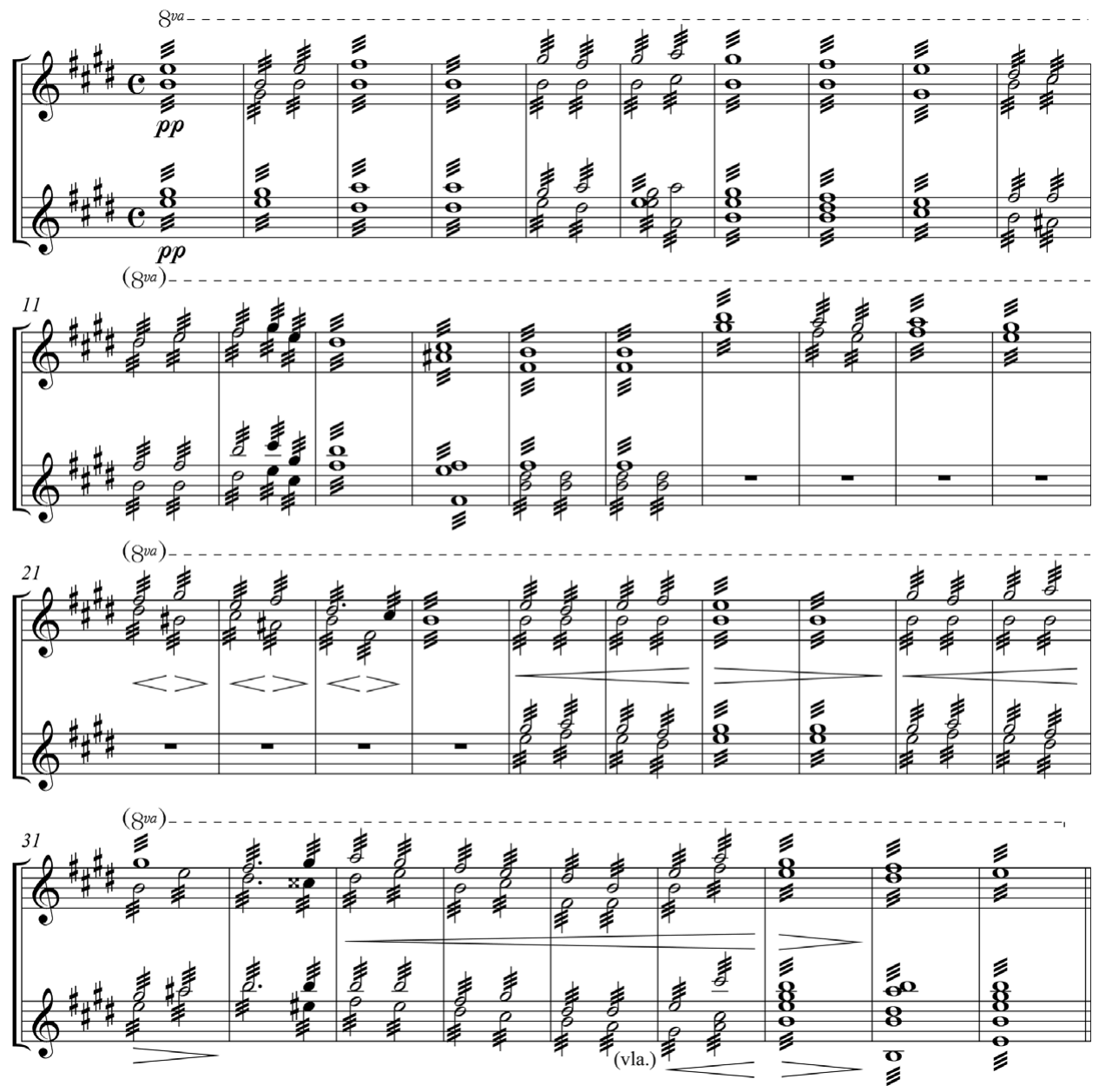

Example 4. Implied Choral Finale: Adeste fideles. William Henry Fry, Santo Claus: Christmas Symphony, VI, mm. 1-39 (Rehearsal P). William Henry Fry Collection, Library Company of Philadelphia.

Symphony. As in the Ninth, too, Adeste fideles returns with the full complement of instruments in a rousing final stroke; although no accounts indicated that the piece was ever performed with a chorus, both the synopsis and Fry's description suggest that his original plan was to include one. But not one reviewer made this connection to the Ninth. ${ }^{51}$

\section{Nature of the Symphony}

To call a piece of music a "symphony" suggests that the composer wanted it to be perceived within a framework of generic integrity: all items within the genre share

${ }^{51}$ On the widespread practice of writing a symphonic choral finale, or implying one, see Mark Evan Bonds, "Beethoven's Shadow: The Nineteenth Century," in The Cambridge Companion to the Symphony, ed. Julian Horton (Cambridge: Cambridge University Press, 2013), 339-41. 
certain essential properties but differ in other external characteristics. ${ }^{52}$ Believing that his music was "serious" or "earnest," and thus worthy of the title "symphony," Fry took offense that Burkhardt and Willis would casually dismiss Santa Claus as something other than a symphonic piece:

But I give the public a symphony, as an instrumental work corresponding in rank and magnitude with The Prophet as an operatic work-a symphony written in the school of romantic and not formalistic Art—novel in design, novel in treatment, novel in effects, novel in instrumentation [...] and your journal dispatches it with a dozen lines-and these, in my judgment, embody a total misapprehension of the intention and spirit of the piece.

Fry was attempting to reshape the genre's conceptual boundaries by defining separate criteria of generic integrity. The standard four-movement schema of classical symphonies diminishes their value, he argued, because it draws unnecessary attention to their superficial features; as he put it, they lack "ars celerem artem" (the quality of true art that conceals its artistry). A better model, he argued, "merges form into force, verisimilitude, and subtle art." External form, internal unity, and the dramatic narrative should all collapse into a single entity, the one indistinguishable from the others.

Willis, predictably, disagreed: "But Santa Claus is not a symphony. You might as well call it an oratorio." A single-movement symphony, he contended, is a contradiction in terms; Fry had broken the so-called "generic contract." ${ }^{53}$ Placing Santa Claus within a different generic tradition, Willis suggested that it was a fantasia, "a one movement piece, of irregular construction. [ ... ] To call it a symphony, where terms have, among artists, so definite a signification, is like calling a cat a dog, or a house a barn. You can do so, but nobody will understand you." Willis argued further that the interior unity of the individual movements contributed to a work's "symphonic unity," but he did not explain why sonata form and motivic development were essential to the symphony, as opposed to merely external characteristics.

Unconvinced, Fry responded that "the four movement business is mere matter of fashion, and fashion sanctifies stupidity." The essence of the symphony lay in the progress of its "musico-dramatic plan," he argued, and the unification of musical form and drama found in a work like Weber's Der Freischütz overture. A fantasia, by contrast, is practically formless- "a piece written at the unchecked will of the composer," as he put it. The debate over Santa Claus concluded with a response from Willis that reiterated the points he made in his previous message; the two had reached an impasse, their differing positions being essentially irreconcilable. They were talking past each other.

Even so, the controversy resonated outside the immediate exchange, for the broader critical reception of Fry's music also tended to focus on the nature of the symphony as a genre-a clear indication that other writers were participating in the transatlantic conversation. Concerning A Day in the Country, a critic for the

\footnotetext{
${ }^{52}$ See Bonds, After Beethoven, 27.

${ }^{53}$ On the concept of the "generic contract" in music, see Jeffrey Kallberg, "The Rhetoric of Genre: Chopin's Nocturne in G Minor," 19th-Century Music 11 (1988): 243-46.
} 
New-York Times remarked prior to the debate that "we do not approve of running the movements into each other, although Mr. Fry has succeeded in connecting his ideas very ably. A momentary cessation contributes to the enjoyability of the various movements of a symphony; indeed all long musical works should, we think, be divided in such a manner that the ear may enjoy a little repose. ${ }^{" 54}$ Several months after, a different critic made the same complaint about Childe Harold: "The symphony is written in one movement, the author, as is well known, rejecting utterly the logic of having what he calls four disconnected movements. It proceeds unbroken, from first to last; the end is the end of all of it, and there are not four ends to four movements, one, two, three, and four, each one with a fresh exordium, argument, and peroration." 55 Whereas these two critics seemed skeptical of the one-movement approach, Burkhardt commented favorably on the concept, noting with a hint of Wagnerian rhetoric, "We look upon [A Day in the Country] in an aesthetic point of view as a cheering sign, indicative of progress in the right direction, of an attempt to throw off the shackles of time-honored conservatism and scientific legitimacy, which have sat brooding, like ill-omened birds, over every attempt to develop, by the extended resources of art, the new ideas of the age." 56

For all their intensity and detail, however, reviewers rarely if ever mentioned European pieces to which Fry's symphonies could have been compared, especially those of Berlioz or Spohr-or even Beethoven's Fifth and Sixth, both of which contain elements that Fry borrowed. Nor did they mention the ongoing European debates about the very same aesthetic and compositional issues they were discussing, despite the fact that they knew these debates were taking place. ${ }^{57}$ Only Fry himself brought up the European climate, but it was to exhibit what he perceived as Willis's hypocritical preference for European works:

\footnotetext{
But Beethoven has done the same thing [painted scenes] in his Pastorale; Weber in his Der Freischütz overture; Mendelssohn in his Midsummer Night's Dream Music; Spohr in his Dedication of Sound: and so does modern Germany generally. And my synopsis of Santa Claus, which I assert thousands are ready to affirm, enabled them to trace as perfectly the music as if the same scenes had been presented on the stage,_-is objected by you! Objected to, though you know that the Philharmonic of this city habitually publishes synopses of the descriptive symphonies of Spohr, Mendelssohn, Gade, and other German composers! $!^{58}$
}

He argued further that if Mendelssohn had used toy instruments in a Christmas piece, it "would have been applauded to the skies by the men who condemn it, or affect to condemn it in me." And he was right: Willis's review of Spohr's colorful Ninth Symphony (Die Jahreszeiten, "The Seasons"), performed by the Philharmonic in November 1853, dwells at length on the composer's skill at "descriptive" writing

\footnotetext{
54 "Amusements," New-York Times, 1 October 1853.

55 "Fry's New Symphony," NYMRCA, 8 June 1854, 201.

56 "Music. Jullien's Concerts," Albion 24 September 1853, 464. Emphasis in the original.

${ }^{57}$ Burkhardt's reference to aesthetic "progress," for example, indicates some degree of familiarity with European musical developments; he was also a native German speaker and would support Fry in the latter (non-aesthetic) stages of the controversy; see Lawrence, Strong on Music, II:492-94.

${ }^{58}$ Emphasis added. "Rejoinder from Mr. Fry," 75.
} 
without once suggesting that this general approach was invalid or mistaken. ${ }^{59}$ And just a week after the Santa Claus premiere, Willis defended Beethoven's use of natural imitation on the grounds that, "Beethoven, for a moment, ceases to be Beethoven, to become-a cuckoo! And, in cuckoo music, the cuckoo herself is certainly the better musician of the two." 60

Willis's seeming reluctance to compare Fry's works to those of their rough contemporaries, especially when these works were performed during the months-long controversy, suggests that he resisted connecting Fry's music to an emerging European trend that favored unconventional forms. Taking this stance allowed him to dismiss Fry as a wild dreamer, thus reinforcing the authoritative position he needed his readers to believe he held. Fry, on the other hand, deliberately constructed an aesthetic lineage for his symphonies that diverged from the genre's traditional history-the precise strategy often taken by his progressive European counterparts. ${ }^{61}$ Indeed, Fry's positions often paralleled those of the Zukunftsmusiker, and at times anticipated them.

\section{Fry and the Zukunftsmusiker}

Willis never openly considered the possibility that Fry's music belonged in the same category as progressive European works and chose instead to focus on the face value of Fry's statements, not their broader musical or intellectual contexts. ${ }^{62}$ For Willis, a symphony could only be a four-movement work. For Fry, composers such as Beethoven, Weber, and Mendelssohn had approximated what a symphony should be, whereas his works marked the most advanced stage of the genre's development (reached via Weber). Willis's disregard of contemporary music during the Santa Claus controversy thus throws into sharper relief the currency of Fry's own ideas within the transatlantic musical world. In many respects they were congruent with those of Franz Brendel and Franz Liszt, both of whom were also developing new theories of descriptive instrumental music and considering its place within the overall history (and future) of music. ${ }^{63}$ As we shall see, how Fry might have encountered these ideas remains mysterious, but the connections are strong.

\footnotetext{
${ }^{59}$ In reviews from the same concert season, Willis similarly praised the descriptive Calm Sea and Prosperous Voyage overture by Mendelssohn and Berlioz's dramatic overture to King Lear, a work that Willis thought disclosed the composer's unheralded genius. Die Jahreszeiten and King Lear in "Musical News from Everywhere. New York," MWઐT, 3 December 1853, 106; Mendelssohn in "Musical News from Everywhere. New York," MW\&T, 21 January 1854, 27. The orchestra also performed Die Weihe der Töne ["Dedication of Sound"] later in the season, which Willis received more coolly in "Musical News from Everywhere. New York," MWঊT, 29 April 1854, 201.

60 "Descriptive Music," MW\&T, 31 December 1853, 137.

${ }^{61}$ Wagner also considered Weber's overtures a turning point in the development of the genre, though he (like Willis) used the term "fantasia," or dramatischen Phantasie, to describe its dramatic unfolding. See his "Über die Ouvertüre," in Gesammelte Schriften und Dichtungen, I:198.

${ }^{62}$ It did not help Fry's case that critics such as Willis tended to judge American composers by a harsher standard than Europeans, or that Fry had posited the American-ness of his symphonic style at a series of lectures given a few months prior to the Santa Claus fiasco. See Lawrence, Strong on Music, II:380-93.

${ }^{63}$ On changes to Brendel's Geschichte der Musik (Leipzig: Bruno Henze, 1852) accommodating Liszt's symphonic poems, see Golan Gur, "Music and 'Weltanschauung': Franz Brendel and the Claims of Universal History," Music \& Letters 93 (2012): 364-66.
} 
As in Fry's assessment of Schumann's symphony, Brendel adopted the view that history was moving inexorably through distinct stages of progress. Following a Hegelian dialectical model, Brendel's conception of musical progress entailed certain elements of the past moving forward (e.g., the idea of tone painting) while others, such as classical forms, were left behind, supplanted by new and original ideas that merged with the remainder. ${ }^{64}$ Skeptical of Wagner's Gesamtkunstwerk concept, which marginalized music without voices, Brendel also constructed a much larger space for instrumental music, particularly descriptive works. One of his important essays from the period presented a history of tone painting that moves through early nature scenes and Beethoven's Sixth Symphony to later descriptive concert overtures, especially those of Mendelssohn. If the technique were to move forward from those pieces, he suggested, the external dimensions of tone painting should become "reborn" in a work's interior nature-essentially what Fry called the merging of "form into force, verisimilitude, and subtle art" anticipated by Weber's overtures. ${ }^{65}$

While Fry's historical vision certainly resonated with Brendel's, it is all the more striking that the American composer's aesthetic outlook also mirrored that of the New German School, which was not expressed with much precision until after the release of Hanslick's polarizing Vom Musikalisch-Schönen in September 1854, well after the Santa Claus controversy had dwindled. ${ }^{66}$ Peter Cornelius (1824-74), a key exponent for the school, wrote that he and his colleagues sought "to renounce the freedom of absolute music and its associated servitude to conventional forms in order to win a freedom of form by giving itself over to a specific poetic object." 67 Liszt likewise adopted Brendel's Hegelianism and, echoing Cornelius, argued that the newness of the present age would be marked by the "union" or "coalescence" [Vereinigung] of instrumental music with poetry, as opposed to mere "linkage" [Verbindung]. ${ }^{68}$ Following from such a union, he argued, a verbal program would become an essential tool for directing the listener's imagination toward the music's inner poetic content. Fry's parallel belief in the union of poetic content and musical technique, as well as the value of a descriptive synopsis, is evident in the published explanations of his works; without the composer's help, listeners would likely have no idea that Fry meant Santa Claus to serve as a metaphor for Christ, or that lush string writing was intended to depict a death scene in a cathedral in The Breaking Heart. ${ }^{69}$

${ }^{64}$ Each of these changes would, in turn, be a manifestation of the Weltgeist, or universal spirit. On Brendel's Hegelianism, see Gur, "Music and 'Weltanschauung,"” 356-62; and Karen M. Stevenson, "The Music Criticism of Franz Brendel" (Ph.D. diss., Northwestern University, 1994), 60-126.

${ }^{65}$ Franz Brendel, "Einige Worte über Malerei in der Tonkunst," NZfM 32 (1850): 244.

${ }^{66}$ See Deaville, “The Controversy Surrounding Liszt's Conception of Programme Music," 107-9.

${ }^{67}$ Peter Cornelius, "Concertmusik," NZfM 41 (8 December 1854): 259, quoted and translated in Bonds, Absolute Music, 215.

${ }^{68}$ See Liszt, "Berlioz und seine Haroldsymphonie." The distinction between Vereinigung and Verbindung appears throughout the essay. On Liszt's general view on progress, see John Williamson, "Progress, Modernity, and the Concept of an Avant-Garde," in The Cambridge History of NineteenthCentury Music, ed. Jim Samson (Cambridge: Cambridge University Press, 2002), 424-59.

${ }^{69}$ Liszt's programs were much less detailed than Fry's and did not always contain a musical "map;" see Williamson, "Progress, Modernity, and the Concept of an Avant-Garde," 306-7. Dahlhaus also emphasizes the technical elements of Liszt's symphonic poems that ostensibly tie them more directly to the symphonic tradition; see Carl Dahlhaus, Nineteenth-Century Music, trans, J. Bradford Robinson (Berkeley: University of California Press, 1989), 236-44. 
Beyond sharing a more or less Hegelian view of historical development and a belief in the aesthetic validity of descriptive music aided by a program, Fry, Brendel, Cornelius, and Liszt all envisioned a higher purpose for art that radiated into social and political life-a position also held by Wagner. Certain critics teased Brendel's circle for emphasizing music's connection to politics, asking, for example, if they could identify four bars of "aristocratic" and "democratic" music or how one might put "freedom of the press, parliament, and popular sovereignty [Volkssouveränetät]" into music. ${ }^{70}$ Likewise, Fry's thoughts about music and politics colored his voluminous writings from Paris and emerged in full force again during the Santa Claus controversy. ${ }^{71}$ Classical forms, he argued, are "only accepted and admired by those ... who take it on trust in music as in religion, in government, and in political economy all things which bear the sanction of ages." Willis, practically proving Fry's point, held firm: "You may attack this musical unity [i.e., sonata form] as you please, FRY. It is a principle deep-seated in the human mind, and you can never displace or ride over it."

Wagner, the New German School, and Fry constructed similar political foes: those who would separate music from the sphere of practical life and consider it art for art's sake. Fry used the terms "mathematical," "mosaic," and "simply symphonic" to describe music without an apparent purpose. Among other terms, including "specifically musical" [ specifisch musikalische], Liszt likewise adopted the metaphor of mathematics to decry listeners who value music for its own sake without considering its deeper meaning beyond external form-a sharp contrast to Hanslick's "tonal forms in motion" [ tönend bewegte Formen]. ${ }^{72}$ Brendel believed that music more than any other art was threatened by "empty formalism."73 And Wagner famously gave such politically unengaged music the high-sounding title "absolute music." 74 All of the progressive figures argued for the creation of a concrete musical repertory that would meet the needs of a new age, and they made common cause against what they perceived as empty music. ${ }^{75}$

70 "Four bars": Joseph Schucht, "Der überwundene Standpunkt der Tonkunst," Allgemeine musikalische Zeitung 50 (1848): 758 . "Freedom of the press": Eduard Krüger, "Beziehungen zwischen Kunst und Politik," Allgemeine musikalische Zeitung 50 (1848): 405.

${ }^{71}$ On these Parisian writings, see Douglas Shadle, "Music of a More Perfect Union: Symphonic Constructions of American National Identity, 1840-1870" (Ph.D. diss., University of North Carolina at Chapel Hill, 2010), 55-64.

72 " [...] die kaleidoscopische Mannichfaltigkeit mathematischer Berechnung." Liszt, "Berlioz und seine Haroldsymphonie," 50. This essay was a response to the first edition of Hanslick's treatise, which uses the same metaphor of music as a kaleidoscope in chapter three, but with positive connotations. See Altenburg, "Vom poetisch Schönen."

73 " [... der die Tonkunst mehr wie jede andere Kunst mit einem leeren Formalismus bedroht." Brendel, "Fragen der Zeit. II: Die Ereignisse der Gegenwart in ihrem Einfluß auf die Gestaltung der Kunst," Neue Zeitschrift für Musik 28 (1848): 195.

${ }^{74}$ As Thomas Grey notes, "Autonomy [signified by the term 'absolute music'] became problematic, for Wagner, when one considered the price exacted by it (music's cultural isolation), which led him to question its status as a positive aesthetic criterion." See Thomas Grey, Wagner's Musical Prose: Texts and Contexts (Cambridge: Cambridge University Press, 1995), 12.

${ }^{75}$ On the politics of the New German School, see James Garratt, Music, Culture, and Social Reform in the Age of Wagner (Cambridge: Cambridge University Press, 2010), 177-80. 


\section{Reading Europe at Mid-Century}

The parallels between Fry's positions and those of the New German School, and between Willis's and Hanslick's, seem to suggest that the American debate participants must have had detailed knowledge of European aesthetic arguments. But several key writings on each side of the debate's European manifestation had not yet appeared. Complicating matters further, in an 1855 review of the New York premiere of Wagner's Tannhäuser overture, Fry explicitly claimed to be unaware of the composer's writings: "Mr. Wagner deserves applause for breaking through the stereotyped form of the symphony [i.e., sonata form]. We have never read any of his works, and know nothing of his processes or theories, but have long been under the impression that a field is open to instrumental forms and means." ${ }^{\prime 6}$ It is entirely possible that Fry was unashamedly lying, actually knew Wagner's theories, andhoping that New Yorkers' lack of knowledge about "Music of the Future" would work in his favor-skillfully manipulated his readers into believing that his radical ideas were completely original. It seems more probable, however, that Fry's (and Willis's) knowledge of the European musical climate was gleaned selectively from printed journals, to which they both had extraordinary access as editors. In Fry's case in particular, his knowledge of contemporary European thought had also become much sturdier as a result of his recent six-year European residency, when he had probably heard some of the latest works by "progressives" such as Berlioz, David, and Wagner and had likely read about Wagner's and Liszt's activities. ${ }^{77}$ Although they had every opportunity to bolster the authority of their respective positions by invoking the names of European figures who shared their perspectives-names they undoubtedly knew—neither Fry nor Willis took this approach. Readers were left to connect the dots for themselves, if they wished.

Throughout his writings following his return to the United States, Fry referred to "modern Germany" only in the vaguest of terms, as if his readers would understand that something was happening "over there," but without being sure quite what it was. Outside of a handful of works, they certainly did not know what modern German music sounded like, for it had not yet been performed in the United States. American music journals in general tended to follow the activities of star performers, not composers, and coverage of the physical "movements" of Liszt and Wagner were scarce into the early 1850s; reports of the aesthetic conflict emerged very slowly. ${ }^{78}$

Willis's strategy for reprinting articles was eclectic and contributed to the slow pace; as a leading journal editor, he had the means and opportunity to remain

76 “The Philharmonic Concert," NYDT, 23 April 1855.

${ }^{77}$ François-Joseph Fétis's disparaging series of articles on Wagner appeared during Fry's final months in Paris, for example, and Fry certainly would have had access to much of the French media coverage of events in Weimar and elsewhere-if he did not travel there himself. There is no convincing evidence that Fry had any degree of German fluency, only French. See Fétis, "Richard Wagner: Sa vie-Son système de rénovation de l'opéra-Ses œuvres comme poète et comme musicien-Son parti en Allemagne-Appréciation de la valeur de ses idées." La Revue et Gazette musicale de Paris 19 (1852): 185-87, 193-95, 201-3, 209-11, 225-27, 242-45, and 257-59.

${ }^{78}$ Knowledge of German musical affairs widened in the late 1860 s and into the 1870 s as newer, "progressive" works were performed much more frequently in the United States and generated concomitant intellectual interest in aesthetics. See, for example, Watson's Art Journal from the period. 
on the cutting edge but chose to reprint recent German-language contributions to aesthetics only sporadically. Between May and July 1853, for instance, he provided English translations of two significant aesthetic articles that appeared first in the German-speaking world: excerpts from the recently published Musikalische Briefe (Leipzig, 1852) by the anti-Wagnerian composer and theorist Johann Christoph Lobe (1797-1881) and Hans von Bülow's controversial polemical essay concerning Henriette Sontag that first appeared in the NZfM in February $1852 .{ }^{79}$ Both essays treated musical aesthetics in some detail, but without the context for understanding them, American readers likely perceived the articles as novel think-pieces rather than the incendiary agents they were intended to be. ${ }^{80}$

Only Dwight, whose journal had an unusually high intellectual tenor, had introduced English-speaking readers directly to the emerging European aesthetic conflict by providing his own translations and commentaries on Wagner's Zürich writings. ${ }^{81}$ These translations included passages with the contentious phrase "absolute music," but the term would have been practically meaningless to Dwight's readers without much framing context. Since these passages were printed in order to prepare readers for listening to Wagner's music for the first time, Dwight did not provide his readers with any opposing viewpoints or much elaborating commentary.

The Fry-Willis controversy reflected the prismatic nature of information exchange illustrated by the dialogue between Dwight and Pohl just months before the debate: they re-interpreted their own vague knowledge of an issue through the lens of idiosyncratic ideological biases. Even if Fry had read the issues of Dwight's Journal that included Wagner's writings and even if he had encountered certain aspects of the European debate during his time in Paris (though it had really only just begun), the local context in which he presented his ideas influenced how they were both transmitted and received. To understand how the debate between Fry and Willis was read in its own time, then, and to ascertain its importance for Americans, we should be mindful that its intellectual sources are perhaps less significant than its residual effects. Notwithstanding the similarities of content, how each manifestation of the debate unfolded was substantially different.

The New Germans and Fry identified a common music-aesthetic target: the specifically musical, represented by abstract instrumental music. Further, they believed that music had the potential to manifest a greater world spirit tied to political life. Beyond these connections, their strategies for reaching the public diverged significantly. Wagner and Liszt transformed the debate into one over repertoire. The musical force to ward off "absolute music" and its kin, they believed, must be a new type of music. Wagner called this force Gesamtkunstwerk, while Liszt called it Programmusik. By shifting the terms of the debate to focus on

79 [Hans von Bülow], "Henrietta Sontag. The Opinion of the Minority," trans. Richard Storrs Willis, MW\&T, 19 March 1853, 177-78 and 193-94. The Lobe reprintings appear in the 2 July, 9 July, and 16 July 1853 issues of $M W \ll T$.

${ }^{80}$ Willis also never reprinted anything written by Bischoff, who had been making arguments similar to Willis's in the Rheinische Musik-Zeitung since at least 1850.

${ }^{81}$ These reprints are found in the following issues of DJM: 4 December 1852 (69-70); 11 December 1852 (76-78); 26 February 1853 (165-66); 5 March 1853 (173-74). These issues, incidentally, were not in the packet Dwight sent to Pohl. 
specific types of musical works, abstract questions about music's political function faded to the background. ${ }^{82}$ Once their concrete musical styles could be mapped onto ideological perspectives, progressives could skirt the issue entirely; merely to write stylistically backward music was to be politically backward as well.

Like his German counterparts, Fry mapped musical style onto political perspectives but chose a different rhetorical framework and consequently struggled to find supporters. Instead of naming his new repertoire and casting it as an alternative to the old- "symphonic dramas" might have sufficed—he stubbornly attempted to change the meanings of older terms, a much more difficult rhetorical strategy. A material consequence was that no one seemed to listen: no one rose to Fry's defense. There was no "New American School." Fry's failure to garner any aesthetic adherents (in print, at least) can be attributed to the lack of what some marketing theorists have called "social currency," or the "stickiness" of an idea that makes it relevant to a particular population. ${ }^{83}$ The later scholarly reception of the aesthetic portion of the debate has consequently tended to treat this failure as a foregone conclusion, thus obscuring the resonance Fry's message might have had among his readers. ${ }^{84}$

In his own day, however, Fry was perceived as a devoted democrat, and he had a compelling message concerning music's future that resonated with the ideas of contemporary writers and visual artists. He only struggled to sell it. Instead of speaking in a language that his readers would understand, he drew on abstract aesthetic and political principles unfamiliar to them. Calling his music "democratic symphonic dramas" might have appealed to readers who would be moved by such political posturing, but he instead chose "symphonies," a word whose meaning was well established but had no widespread political significance, no matter how progressive and politically vital Fry might have intended his music to be. The essence of Fry's aesthetic position was that music's dramatic power could and should harness the spirit of democracy for the greater good. Why would he write a Santa Claus symphony, then? Why not something bolder-a symphony on the subject of slavery perhaps, which would reach to the core of American politics and might attempt to effect truly radical change? His readers, and his listeners, might have approved. ${ }^{85}$ As it was, print turned out to be a poor channel for conveying his provocative ideas. And by the time the controversy was over, Anthony Burns had been caught and returned to his cruel master.

\section{Re-Reading Nineteenth-Century Musical Print Culture}

No major figure in the United States became a standard-bearer for Fry's ideas following the debate's conclusion, and even Fry himself did not return to them in

\footnotetext{
${ }^{82}$ See Bonds, Absolute Music, 210-18.

${ }^{83}$ See Jonah Berger, Contagious: Why Things Catch On (New York: Simon and Schuster, 2013), 29-60. On "stickiness," see Malcolm Gladwell, The Tipping Point: How Little Things Can Make a Big Difference (New York: Back Bay Books, 2002), 89-132.

${ }^{84}$ See, for example, Lawrence, Strong on Music, II: 383.

${ }^{85}$ On the multinational character of abolitionism at this time, see Mischa Honeck, We Are the Revolutionists: German-Speaking Immigrants and American Abolitionists After 1848 (Athens: University of Georgia Press, 2011).
} 
his subsequent compositions. This result can be explained in large part by the fact that the music of Fry's closest aesthetic companions-Wagner, Liszt, and Berliozarrived in full force on American shores shortly after the debate's conclusion; his music no longer would have occupied as radical a cachet as it had for a brief time in $1854 .^{86}$ Fry's ideas did, however, generate social currency among a particular set of readers, though probably not of the kind that he intended. The refraction of knowledge and ideas spurred by the multilingual and multinational character of transatlantic print culture transformed Fry's positions into a different form of cultural capital during a humorous sideshow that took place alongside the controversy itself and would have a significant impact on the debate's final link: the antislavery Evening Post review. Readers—-then and now—favoring Willis's position likely missed this residual effect.

Just as the Santa controversy was building momentum in late January 1854, Dwight printed an essay entitled "A New 'Jupiter' among Symphonies." A fabricated correspondence from Berlin, it described a performance of a ridiculous "pictorial symphony" called Das Tongemalt Kauffmanns Leben Gedicht ["The Tone-Painted Poem of a Businessman's Life"], by one "Herr Löstiswitz." To a trained musician, the description of the work reads like a remarkably astute parody of Fry's Santa Claus synopsis, which had been printed in full in The Albion, a literary magazine, on 14 January:

Fry: The first movement, which is slow, opens with a single musical measure of Trumpet solo, being the celestial precursor to the announcement of the glad tidings of the Saviour's coming birth. This is followed by some tender notes on the horns, suggestive that the Messiah's advent is to be one of love. The phrase is repeated in a fresh key. It is then taken up by the whole orchestra as though the assembled hosts of heaven joined in the declaration. This is followed by some soft music, the first violins having a volant trill, accompanied variously by the other stringed instruments in a singing strain, while the Flute, Clarionet, Hautboy and Bassoon fly seraph-like through different regions of musical space. After a momentary pause, M Koenig on his Cornet, discourses in an Adagio-Cantabile, on the impending advent of the Saviour-which if sung could be recited in words taken from the Bible.

Löstiswitz: A pause ensues. Then there begins a plaintive warbling strain on the oboe, accompanied by the ophicleides and one gong. This marks the first entrance of the boyman into mercantile life. The lingering remembrances of his boyish sports and pleasures (graphically depicted by the touching accents of the oboe in E major) are brought effectively into contrast with the rough rebukes and reproaches of the senior clerk, conveyed by the bassi in $\mathrm{C}$ minor. Want of punctuality, and inaccuracy in the details of business, are now sharply urged against him by the violins, in staccato passages contretemps.

The similarity in literary style is uncanny, and any readers familiar with the synopsis (either from a concert or the magazine) almost certainly would have made the

${ }^{86}$ The ascendance of this music in American culture has been well documented: see Mark McKnight, "Wagner and the New York Press, 1855-1876," American Music 5 (1987): 145-55; Rena Chamin Mueller, "Liszt (and Wagner) in New York, 1840-1890," in European Music and Musicians in New York City, 1840-1900, ed. John Graziano (Rochester, NY: University of Rochester Press, 2006), 50-70; and Ora Frishberg Saloman, "Presenting Berlioz's Music in New York," in European Music and Musicians, 29-49. 
connection. ${ }^{87}$ But whereas Fry's synopsis is a believable description of the actual piece, the Löstiswitz account contains a degree of terminological infelicity that reveals its comic intent-violins cannot play "contretemps."

Two weeks later, the editor of The Albion reprinted the article from Dwight's with the observation that readers of Fry's synopsis would likely find the piece humorous. On the same day, in a complete coincidence, Dwight referred to Fry and Löstiswitz together in a lengthy commentary on the brewing controversy: "And Mr. Fry and Mr. Bristow, and 'Herr Löstiswitz' himself, whose programme rivals Fry's, are sure to be accepted just so soon as the world shall see that they have done what they themselves suppose they have." 88 Bristow, as Dr. F. would let Bischoff's readers know, had no pretensions of progressivism.

In March, The Knickerbocker reprinted the Löstiswitz program and added, "The 'synopsis' given by Mr. William H. Fry, (an accomplished musical composer, and an excellent man,) of his Santa Claus Symphony has provoked a description, by a musical contemporary, of an imaginary concert given in Berlin, $[\ldots]$ and the following is a specimen of a portion of its 'action.' It would make a Quaker 'laugh out in meeting." 89 The insinuation was that Fry had created such a stir in Europe that even Berlin's musicians were becoming involved in the fray.

By April, interest in the Löstiswitz story had abated, likely because the Fry-Willis controversy itself had moved from Santa Claus to other issues. But such "musical fooling" did not stop there. Freeman Hunt, founder and editor of the well-respected Merchants' Magazine and Commercial Review, reprinted the Löstiswitz program in an 1856 collection of miscellany for "men of business." ${ }^{\text {"90 }}$ A year later, at the height of summer, the editor of Harper's Weekly pined for "a cool symphony, like Beethoven's Pastorale" and, slyly resurrecting the old debate over Santa Claus, asked, "Why does not Mr. Fry compose a Polar Sonata, with reminiscences of icebergs, hummocks, frozen fingers, and white bears? With the thermometer at a hundred in the shade, it would obtain a succès fou. Who is there that would not go to be harmonically cooled off?"91

The idea that music supported by a literary narrative could have concrete effects on listeners- the very idea put forward by Fry and rejected by Willis—had taken on a life of its own in the months and years following the controversy. But no one in all of this fooling seemed to realize that the Löstiswitz article had first appeared in the Musical World of London in 1839 and had nothing to do with Fry. ${ }^{92}$ A fickle print culture had struck again.

${ }^{87}$ The entire piece may be found in "A New 'Jupiter' Among Symphonies,” DJM, 21 January 1854, 122-23. Fry's synopsis was reprinted as "A Literary Curiosity," The Albion, 14 January 1854, 21.

88 "Musical Fooling," The Albion, 4 February 1854, 57; and "Mr. Fry and His Critics," DJM, 4 February 1854, 141.

89 "Editor's Table," The Knickerbocker (March 1854): 316-17. The New-York Times also reprinted a lengthy excerpt, but without further commentary: "Merchant Life Done in Music," 4 March 1854.

${ }_{90}$ Freeman Hunt, Worth and Wealth: A Collection of Maxims, Morals, and Miscellanies for Merchants and Men of Business (New York: Stringer and Townsend, 1856), 170-73.

91 "The Man About Town. Summer Music," Harper's Weekly, 22 August 1857, 531.

92 "Progress of Descriptive Music. Latest Triumph," The Musical World (London), 11 April 1839, $222-24$. 
This oddly anachronistic fallout from the Santa Claus controversy stemmed from a prismatic refraction that was spread out over the course of nearly fifteen years. Dwight, or one of his readers who mailed him the story, must have held onto the Musical World original and thought it germane to the Santa Claus situation; we may never know how it landed on Dwight's desk. The source, whoever it was, had co-opted and re-interpreted information received from the other side of the Atlantic and, in turn, invested it with greater social currency in the United States than it had accrued in 1839, when potential American readers would have had no frame of reference for processing it. ${ }^{93}$ Santa Claus and the furor surrounding it had created a groundswell of interest in descriptive music that caused several different writers to keep Löstiswitz alive and to poke fun at the concept over the course of many years; the Löstiswitz story's actual origin did not matter as much as the fact that participants believed it was somehow related to their own experiences as listeners - the very essence of social currency.

Not merely a humorous sideshow, however, the protracted evolution of the Löstiswitz story is a microcosm of how the aesthetic component of the Fry-Willis controversy unfolded and is indicative of its broader consequences. Fry's aesthetic ideology shared certain features with that of the so-called Zukunftsmusiker and had begun to take shape over a period of roughly eight years by the time the controversy started; by his own admission, however, he had no knowledge of a significant cornerstone of the new European aesthetic_Wagner's theories. Willis's positions were similarly current (despite seeming conservative), though he made no reference at all to contemporary discourses that might have supported them; he may not have been an avid reader of Bischoff's journal, for instance, but the character of his argumentation certainly matched. Each side of the controversy cribbed and modified pre-existing ideas whose precise origins were merely incidental and, in turn, shaped these positions to suit the topic at hand. This pattern recurred throughout the nineteenth century.

On the one hand, music periodicals such as Willis's Musical World and Times reported relatively faithfully on musical events and now serve as vital sources of information about musical culture and the individuals driving it. The aesthetic portion of the Fry-Willis controversy, for example, can be read in its transatlantic context this way: Fry created his own brand of "Music of the Future" while Willis wrote his own miniature treatise on "the musically beautiful," whether they knew it or not. On the other hand, music periodicals were interlaced within the larger matrix of print culture, with its twists, turns, and unpredictable exchanges. If we are lucky, uncovering their functions within this matrix reveals something about how they were read by their initial readers-that is, subscribers and their social circles_-and thus what they might have meant.

American readers, as it turns out, were not as interested in the aesthetic posturing of either Fry or Willis as they were in what caused the fracas in the first placethe colorful synopsis of Santa Claus distributed at performances and reprinted in a national literary magazine. The Löstiswitz story lifted by Dwight (and others)

\footnotetext{
${ }^{93}$ The piece was not reprinted in the United States at that time anyway, and any readers would have had to be Musical World subscribers.
} 
only piqued readers' interest further. And the very idea that music, or a symphony specifically, could have significance beyond itself-Fry's most central argumentcaught like wildfire. It had created a community of insiders who were "in" on the joke.

At least one of Fry's readers, however, did not see the issue as a joke and instead treated it with gravity: the author of the grisly Evening Post account of the fictional "Plantation Symphony" performance. In the end, this article was a satirical parody of the Löstiswitz story, and in turn a reinterpretation of Fry's Santa Claus synopsis. It was thus removed three times from the London original but made subtle references to all of the intervening documents. ${ }^{94}$ The anti-German insinuation behind the name Treiberneger, for example, is a direct parallel to the name Löstiswitz, while the cracking of Santa's whip in Santa Claus finds a counterpart in the lashing of Anthony Burns, the slave who dared to read, in the symphony's first movement. And was it really Beethoven's Ninth that inspired the "choral finale" to the Treiberneger piece? Or Fry's vague references to a chorus in Santa Claus? The Löstiswitz story contained no such reference.

Drawing fully on the controversy itself, the review also spoke directly to the power of music - or at least the power of the idea of music - to effect concrete political change through the representation and disclosure of ideas, again the very notion put forward by Fry and the New German School and rejected by Willis, Hanslick, and Bischoff. The complex web of imagery in the Evening Post review assumes that readers would have known the details of Anthony Burns's fugitive slave trial, which had been widely publicized by 1855 , as well as a host of classical and popular musical selections. But most important of all, a reader would have had to know why descriptive music would be such an effective medium for satire. If readers were to take the word of Fry's critics, the satire would have been meaningless. And of course had it not been for Fry, the writer likely never would have been inspired to compose this potent article at all. The piece was entirely dependent on Dwight's choice to reprint the Löstiswitz story, as well as the ongoing fabricated connection between Fry and Löstiswitz. The Evening Post writer must have believed that a large community of readers would understand the purpose of the story after having been introduced to Fry's arguments.

Throughout the nineteenth century and beyond, the erratic paths that ideas followed from place to place in print, especially across the Atlantic Ocean, continually shaped how Americans perceived themselves in relation to each other as well as to Europeans, and vice versa. Simply put, the literate class depended on print for both knowledge acquisition and identity formation. Consequently, the asymmetries of information brought on by print culture's winding pathways frequently netted unexpected results, not least of which was a satirical but profoundly moving review of a bone-chilling programmatic symphony published by one of the nation's leading antislavery advocates. Print culture was indeed the condition of possibility for this entire story to unfold. How did Santa Claus become a slave driver? By cracking his

\footnotetext{
${ }^{94}$ This article, incidentally, took a journey of its own as it was reprinted in the Anti-Slavery Bugle (Salem, OH), 9 June 1855, and The National Era (Washington, D.C.), 28 June 1855, and perhaps elsewhere.
} 
whip and riding his sleigh into an abolitionist's post office box, while carrying a sack filled with choice reading material.

\section{Appendix}

Evening Post Review

\section{ANOTHER GRAND SYMPHONY! CHEERING FROM THE SOUTH!}

Under this heading, a correspondent sends us an account of a new and highly original musical work, recently produced in Richmond, Va., by a German gentleman of that State, one Dr. Treiberneger ("Nigger-driver"), who, it is suggested, was inspired to compose his "Plantation Symphony" by the success which has attended the efforts of Herr Lostiswitz and other writers of descriptive music in Germany. Dr. Treiberneger, it would seem, had gone to Virginia laden with prejudices against the peculiar institution of that State, which were only finally conquered when he became, by marriage, the possessor of a wife and a plantation stocked with one hundred negroes. This auspicious event is hinted at in various tender love passages scattered through his symphony. However, from this moment, very little investigation served to convince the Doctor of the weaknes [sic] and injustice of his former prejudices against the institution he now so justly celebrates, and his symphony may be regarded as the voice of one coming to the light. Our correspondent, who seems to have been so fortunate as to be present at the production of this great work, proceeds as follows.

"Amongst those present to listen I observed Senator Mason, ${ }^{95}$ (author of the fugitive slave bill,) Judge Douglas, ${ }^{96}$ (of the Nebraska bill,) Rev. Mr. Stringfellow, ${ }^{97}$ (author of a Bible-Slavery pamphlet,) Mr. Suttle, ${ }^{98}$ (owner of Tony Burns,) Rev. Nehemiah Adams ${ }^{99}$ and E.G. Loring, ${ }^{100}$ who were the only persons from the North. The presence of these distinguished gentlemen excited much attention. It was a proud moment for Treiberneger. He came forth to lead the orchestra, and was

\footnotetext{
${ }^{95}$ James Murray Mason (1798-1871), U.S. Senator from Virginia. Drafted the Fugitive Slave Law of 1850 that compelled all captured runaway slaves to be returned to their owners.

${ }^{96}$ Stephen A. Douglas (1813-61), U.S. Senator from Illinois (called "Judge" because of his service on the Illinois Supreme Court). Introduced the Kansas-Nebraska Act of 1854 that allowed the new territories of Kansas and Nebraska to determine their slaveholding status through the popular vote, thus upending the Missouri Compromise of 1820.

${ }^{97}$ Thornton Stringfellow (1788-1869), Baptist minister in Culpeper County, Virginia. Wrote several biblical justifications of slavery, including A Brief Examination of Scripture Testimony of the Institution of Slavery (Washington, D.C.: Printed at the Congressional Globe Office, 1850 [1841]).

${ }^{98}$ Charles F. Suttle (1818?-81?), slave owner from Alexandria, Virginia. Became embroiled in controversial fugitive slave lawsuit concerning Anthony Burns.

${ }^{99}$ Nehemiah Adams (1806-78), pastor of Union Congregational Church, Boston, MA. After traveling to the South, wrote A South-Side View of Slavery (Boston: T. R. Marvin, 1854), a positive portrayal of slave life that angered abolitionists.

${ }^{100}$ Edward Greely Loring (1802-90), commissioner of Massachusetts Circuit Court. Ordered the return of Burns to Suttle under the Fugitive Slave Act and so angered local abolitionists that he was eventually removed from his post by a Republican governor.
} 
received by an applause in advance-justified by his wealth and the character of his subject. He seemed to be a man of about fifty, short, thickset-a face which reminds me much of the likeness of the poet Herrick. He bowed gracefully, waved his baton, and the symphony burst upon us.

"How shall I describe this great work of art! How shall I utter the ineffable! I rejoice that men have imaginations everywhere, or I should despair of conveying any impression. Dr. Treiberneger, with singular originality, has commenced the symphony (which is in B flat) with the movement Andante graziazo [sic]. The buzzbuzz and hum-hum of conversation has ceased, the perfect quiet of the audience is uninterrupted, save by an occasional spitting of tobacco-when the grateful strains steal forth with enchanting power. The plantation stretches out before you, with graceful, undulating beauty. I had, as this beautiful scene arose, memories of the beautiful themes of Haydn's Creation. For instance, where the tobacco field arises, making 'eye-music,' one is reminded of the passage, With verdure clad, \& c.; and when the cotton field came into view I could hear the words, Here shoots the healing plant. With this for a background, the Virginia gentleman is seen going forth with his wife in a coach, to take a ride around the estate, and to see the hands at work. The music here was similar in movement, though superior in effect, to Haydn's 'In native worth and honor clad.' With one accord, the audience felt that this was a fitting description of Dr. T. and his plantation with negroes; and for a little while the Andante passed-(where the driver was mounting to the box, on a figure skillfully carried from the cellos back to the second violin, ending with the crack of a whip in C sharp) - because the great applause which this great man received with modesty and yet dignity. The rest of the Andante brings the carriage to the place where negroes are collected at work. It closes with the old and favorite air of Old Virginny never tire, to which some one, whom I suspected as an incendiary, sitting behind me, added the words, never tires because it goes so tarnation slow. The Andante closed, time was allowed for gentlemen to take refreshment, which I observed Douglas, Mason, and others did.

"The next movement is Allegro molto e con brio. The carriage arrives where other negroes have been put to work, but in the absence of the overseer have betaken themselves to lolling, singing, dancing. This was a happy thought in the composer, inasmuch as it allowed the introduction of much of the life and incident peculiar to the South. The melody of 'Old Uncle Ned' is heard-faintly at first, then in full chorus. Then is heard a shuffle, as of a jog, (this on the oboe and second violin, in a few quick notes, in A flat,) whilst a slight adagio shows several idling under a tree. The carriage is not yet seen! But we are then taken there, and in a few passages of great brilliance, in what Mrs. Browning calls the 'sad perplexed minor,' have a lamentation over the idleness of negroes, their deceit and indisposition to work. The conversation on this subject is carried on in the carriage- the violoncello representing the master; and the flute, varied by clarionet, representing the lady(every one thinking of the accomplished Mrs. T.!) The characteristic laziness of these blacks, and dishonesty in stealing time from their master, is eloquently brought out; and it is seen from a few notes in the opheiclide [sic], that the present instance demands decided and severe measures. The master's resolution is given in a few base $[$ sic $]$ notes. 
"But the carriage has drawn near. A little scherzo describes their hurrying to their work; but it is too late! They have sinned; they must suffer! A few flashes of the eye in A major announce that a storm is coming on in plantation affairs. They gather together at a barn, where punishment is to be given. The overseers are all put into requisition, with their cowhides. A movement very strong, and resembling the storm in the Pastorale of Beethoven, represents the wailings of the whipped and the warning voice of the master, (violoncello,) and the firm though moderate tones of the lady, saying 'you know I've taught you better,' (flute, C sharp.) One fellow, who was found reading when he ought to have been working, is whipped more than the rest, (in scores.) Strong emotion for a few bars. The evil effects of teaching negroes to read are descanted upon with a movement like that of the Sonata appassionata. (Mr. Suttle here had tears in his eyes, and his hand was seized by Judge Douglas convulsively.) And with these various and conflicting emotions the Allegro ceased; and, as before, the audience retired a few moments to the bar.

"The Scherzo. By a few sudden strokes, we are warned that something wrong has occurred. A few clear notes on the trumpet inform us that Tony, the one flogged for reading, has run away. We have here mingled the confusion consequent on such an event, and a lamentation over the ingratitude of negroes and the depravity of the human heart. (Rev. N. Adams's eyes were seen upturned. Senator Mason mutters, with emotion, 'Dam shame.' Com. Loring says he'll 'see justice done the master.' Douglas is heard to say, patriotically, 'Bri the' da' nigger to m'-I'll wallupim!')

"Nothing now heard but the excited cries of the hunters, the barking of the hunting dogs, the cries of the silly parents and relatives of Tony. The Scherzo ceases-Tony not being found.

"The Finale. I do not hesitate to pronounce this the greatest stroke of artistic genius in modern times. In this the true power of Treiberneger stands forth confessed. In a few rapid and joyful notes in the major key we are informed that Tony is discovered. And we are soon introduced, (with some difficulty arising from bayonets,) into the United States Courtroom at Boston. The Commissioner comes forth under a grand flourish of trumpets, playing 'Star-Spangled Banner.' The prisoner is bought in to 'Old Folks at Home,' to touch his stony heart, if possible. The examination of witnesses, addresses of counsel, excitement in the courtroom, are finely given. (I thought the tempos a little too quickly taken here.) Then follows crash after crash of tremendous power, wherein Justice triumphs over the mob; wherein Tony's sin is punished; you can feel the presence of an advancing army, (such as Jullien says in the 5th symphony;) Tony is borne down, to the tune of Yankee Doodle, to a revenue cutter, and on amid the winds and waves to old Virginia, (air, 'Carry me back,') skillfully brought in. Here he is received on the plantation. The negroes all assemble, and those of the neighbors who have requested that their slaves may have an admonition. Tony is stripped and tied in a few $\mathrm{c}(\mathrm{h})$ ords of great strength. He is cowhided for an hour. It is repeated in a week. He is then sold at auction. The whole closes with a splendid arrangement of 'Hail Columbia, happy land,' which makes this the only symphony, besides Beethoven's 9th, which ends in a vocal chorus, since the whole crowd united in the strain. Nine cheers were then given for Dr. Treiberneger, and three for each of the distinguished gentlemen present, until it came to Mr. Loring, who had nine. 
"I understand that this great work of art is to be produced next fall in the city of Washington, when Congress assembles; and I believe Commissioner Loring declared that it would have a fine effect to introduce it into Boston and other large cities in the Union."

\section{References}

\section{Archival Sources}

Theodore Thomas Collection, Rosenthal Archives, Chicago Symphony Orchestra William Henry Fry Collection, Library Company of Philadelphia

\section{Nineteenth-Century Periodicals}

The Albion (New York)

Anti-Slavery Bugle (Salem, OH)

Dwight's Journal of Music (Boston)

Harper's Weekly (New York)

The Knickerbocker (New York)

The Musical Magazine (Boston)

Musical World (London)

Musical World and Times (New York)

The National Era (Washington, D.C.)

New-York Daily Tribune

New-York Evening Post

New-York Musical Review and Choral Advocate

New-York Times

Watson's Art Journal

\section{Nineteenth-Century Articles and Books}

The Boston Slave Riot, and Trial of Anthony Burns. Boston: William V. Spencer, 1854. Bowen, Eli. The United States Post-Office Guide. New York: D. Appleton and Co., 1851.

Brendel, Franz. "Einige Worte über Malerei in der Tonkunst," Neue Zeitschrift für Musik 32 (1850): 241-44 and 249-50.

_ . "Fragen der Zeit. II: Die Ereignisse der Gegenwart in ihrem Einfluß auf die Gestaltung der Kunst," Neue Zeitschrift für Musik 28 (1848): 193-96.

- Geschichte der Musik in Italien, Deutschland, und Frankreich. Von den ersten christlichen Zeiten bis auf die Gegenwart. Zweiundzwanzig Vorlesungen gehalten zu Leipzig in Jahre 1850. Leipzig: Bruno Henze, 1852.

Clarke, James Freeman. The Rendition of Anthony Burns: Its Causes and Consequences. A Discourse on Christian Politics Delivered in Williams Hall, Boston, on Whitsunday June 4, 1854. Boston: Crosby, Nichols, \& Co. and Prentiss \& Sawyer, 1854.

Cornelius, Peter. “Concertmusik.” Neue Zeitschrift für Musik 41 (1854): 257-59. 
F., Dr. "Musicalische Zustände in den Vereinigten Staaten von Nordamerica." Niederrheinische Musik-Zeitung für Kunstfreunde und Künstler 2 (1854): 105106 and 113-16.

Fétis, François-Joseph. "Richard Wagner: Sa vie-Son système de rénovation de l'opéra-Ses œuvres comme poète et comme musicien-Son parti en Allemagne-Appréciation de la valeur de ses idées." La Revue et Gazette musicale de Paris 19 (1852): 185-87, 193-95, 201-203, 209-11, 225-27, 242-45, and 257-59.

Fry, William Henry. “A Letter from Mr. Fry.” Musical World and Times 8 (1854): 29-31 and 34.

—. "Rejoinder from Mr. Fry." Musical World and Times 8 (1854): 74-76.

Hoplit [Richard Pohl]. "Ein Blick nach dem 'fernen Westen'. Offenes Sendschreiben an Mr. J. S. Dwight.” Neue Zeitschrift für Musik 39 (1853): 269-73.

Hunt, Freeman. Worth and Wealth: A Collection of Maxims, Morals, and Miscellanies for Merchants and Men of Business. New York: Stringer and Townsend, 1856.

Krüger, Eduard. "Beziehungen zwischen Kunst und Politik." Allgemeine musikalische Zeitung 50 (1848): 405.

Liszt, Franz. "Berlioz und seine Haroldsymphonie." Neue Zeitschrift für Musik 43 (1855): 25-32, 37-46, 49-55, 77-84, and 89-97.

Mason, Lowell. Musical Letters from Abroad: Including Detailed Accounts of the Birmingham, Norwich, and Dusseldorf Musical Festivals of 1852. New York: Mason Brothers, 1854.

Ritter, Frédéric Louis. Music in America. New York: Charles Scribner's Sons, 1883.

Schucht, Joseph. "Der überwundene Standpunkt der Tonkunst." Allgemeine musikalische Zeitung 50 (1848): 536-38 and 755-59.

Stevens, Charles Emery. Anthony Burns: A History. Boston: John P. Jewett and Co., 1856.

Wagner, Richard. Gesammelte Schriften und Dichtungen. 4th ed. 10 vols. Leipzig: C. F. W. Siegel, 1907.

Willis, Richard Storrs. "Reply to Mr. Fry, of the Tribune." Musical World and Times 8 (1854): 37-39.

— "Reply to Mr. Fry of the Tribune, Number II." Musical World and Times 8 (1854): 85-87.

\section{Secondary Sources}

Acree, William Garrett, Jr. Everyday Reading: Print Culture and Collective Identity in Rio de la Plata, 1780-1910. Nashville, TN: Vanderbilt University Press, 2011.

Altenburg, Detlef. "Vom poetisch Schönen: Franz Liszts Auseinandersetzung mit der Musikästhetik Eduard Hanslicks.” In Ars Musica, Musica Scientia: Festschrift Heinrich Hüschen zum fünfundsechzigsten Geburstag am 2 März 1980, ed. Detlef Altenburg, 1-9. Köln: Gitarre und Laute, 1980.

Anderson, Benedict. Imagined Communities: Reflections on the Origin and Spread of Nationalism. Rev ed. London: Verso, 2006.

Berger, Jonah. Contagious: Why Things Catch On. New York: Simon and Schuster, 2013. 
Bomberger, E. Douglas. "The German Musical Training of American Students, 1850-1900.” Ph.D. diss., University of Maryland at College Park, 1991.

Bonds, Mark Evan. Absolute Music: The History of an Idea. New York: Oxford University Press, 2014.

- After Beethoven: Imperatives of Originality in the Symphony. Cambridge, MA: Harvard University Press, 1996.

. "Beethoven's Shadow: The Nineteenth Century." In The Cambridge Companion to the Symphony, ed. Julian Horton, 323-43. Cambridge: Cambridge University Press, 2013.

- "Symphony, II: 19th Century." Grove Music Online. http://www. oxfordmusiconline.com/subscriber/article/grove/music/27254.

Broyles, Michael. "Music of the Highest Class": Elitism and Populism in Antebellum Boston. New Haven, CT: Yale University Press, 1992.

Cazden, Robert. A Social History of the German Book Trade in America to the Civil War. Columbia, SC: Camden House, 1984.

Chase, Gilbert. America's Music: From the Pilgrims to the Present. Music in American Life. Rev. 3rd ed. Urbana: University of Illinois Press, 1987.

Curtis, Robert Lee. Ludwig Bischoff: A Mid-Nineteenth-Century Music Critic. Köln: A. Volk, 1979.

Davison, Mary Veronica. "American Music Periodicals, 1853-1899.” Ph.D. diss., University of Minnesota, 1973.

Dahlhaus, Carl. Nineteenth-Century Music. Trans. J. Bradford Robinson. Berkeley: University of California Press, 1989.

Deaville, James A. “The Controversy Surrounding Liszt's Conception of Program Music." In Nineteenth-Century Music: Selected Proceedings of the Tenth International Conference, ed. Jim Samson and Bennett Zon, 98-124. Aldershot, Hants, UK: Ashgate, 2002.

Dennison, Sam and Martha Furman Schleifer, eds. Three Centuries of American Music: A Collection of Sacred and Secular Music. Vol. 9, American Orchestral Music 1800 through 1879. Ed. Sam Dennison. Boston: G.K. Hall and Co., 1992.

Dooley, Brendan, ed. The Dissemination of the News and the Emergence of Contemporaneity. Surrey, UK: Ashgate, 2010.

Ellis, Katharine. Music Criticism in Nineteenth-Century France: La Revue Gazette et Musicale. Cambridge: Cambridge University Press, 1995.

Fleche, Andre M. The Revolution of 1861: The American Civil War in the Age of Nationalist Conflict. Chapel Hill: University of North Carolina Press, 2012.

Frank, Albert J. von. The Trials of Anthony Burns: Freedom and Slavery in Emerson's Boston. Cambridge, MA: Harvard University Press, 1998.

Frisch, Walter. Brahms: The Four Symphonies. New York: Schirmer, 1996.

Garratt, James. Music, Culture, and Social Reform in the Age of Wagner. Cambridge: Cambridge University Press, 2010.

Gladwell, Malcolm. The Tipping Point: How Little Things Can Make a Big Difference. New York: Back Bay Books, 2002.

Goodman, Glenda. "Musical Sleuthing in Early America: 'Derry Down' and the XYZ Affair." Common-place 13 (Winter 2013). http://www.common-place.org/ vol-13/no-02/goodman/. 
Grey, Thomas S. Wagner's Musical Prose: Texts and Contexts. Cambridge: Cambridge University Press, 1995.

Gur, Golan. "Music and 'Weltanschauung': Franz Brendel and the Claims of Universal History.” Music \& Letters 93 (2012): 350-73.

Habermas, Jürgen. The Structural Transformation of the Public Sphere. Trans. Thomas Burger and Frederick Lawrence. Cambridge, MA: MIT Press, 1989.

Henkin, David M. City Reading: Written Words and Public Spaces in New York. New York: Columbia University Press, 1998.

- The Postal Age: The Emergence of Modern Communications in NineteenthCentury America. Chicago: University of Chicago Press, 2006.

Hepokoski, James. "Beethoven Reception: The Symphonic Tradition.” In The Cambridge History of Nineteenth-Century Music, ed. Jim Samson, 424-59. Cambridge: Cambridge University Press, 2002.

Honeck, Mischa. We Are the Revolutionists: German-Speaking Immigrants and American Abolitionists After 1848. Athens: University of Georgia Press, 2011.

Hruschka, John. How Books Came to America: The Rise of the American Book Trade. Penn State Series in the History of the Book. University Park, PA: Penn State University Press, 2012.

Kallberg, Jeffrey. “The Rhetoric of Genre: Chopin's Nocturne in G Minor.” 19thCentury Music 11 (1988): 238-61.

Lawrence, Vera Brodky. Strong on Music: The New York Music Scene in the Days of George Templeton Strong. 3 vols. Chicago: University of Chicago Press, 1995-99 [1988].

—. "William Henry Fry's Messianic Yearnings: The Eleven Lectures, 1852-53." American Music 7 (1989): 382-411.

Leypoldt, Günter. Cultural Authority in the Age of Whitman: A Transatlantic Perspective. Edinburgh: Edinburgh University Press, 2009.

Liley, Thomas. "Invention and Development." In The Cambridge Companion to the Saxophone, ed. Richard Ingham, 1-19. Cambridge: Cambridge University Press, 1998.

Maltz, Earl M. Fugitive Slave on Trial: The Anthony Burns Case and Abolitionist Outrage. Landmark Law Cases and American Society. Lawrence: University of Kansas Press, 2010.

McKnight, Mark. "Wagner and the New York Press, 1855-1876.” American Music 5 (1987): 145-55.

Mueller, Rena Charmin. “Liszt (and Wagner) in New York, 1840-1890.” In European Music and Musicians in New York City, 1840-1900, ed. John Graziano, 50-70. Eastman Studies in Music. Rochester, NY: University of Rochester Press, 2006.

Newcomb, Anthony. "Once More 'Between Absolute and Program Music': Schumann's Second Symphony,” 19th-Century Music 7 (1984): 233-50.

Newman, Nancy. Good Music for a Free People: The Germania Musical Society in Nineteenth-Century America. Eastman Studies in Music. Rochester, NY: University of Rochester Press, 2010.

Nicholson, Bob. "'You Kick the Bucket; We do the Rest!': Jokes and the Culture of Reprinting in the Transatlantic Press." Journal of Victorian Culture 17 (2012): 273-86. 
Pederson, Sanna. "Defining the Term 'Absolute Music' Historically," Music \& Letters 90 (2009): 240-62.

Pratt, Mary Louise. Imperial Eyes: Travel Writing and Transculturation. 2nd ed. New York: Routledge, 2008.

Preston, Katherine K. "American Orchestral Music at the Middle of the Nineteenth Century: Louis Antoine Jullien and George Bristow's Jullien Symphony." In Symphony No. 2 in D Minor, Op. 24 ("Jullien"), by George Frederick Bristow, xvcvi. Ed. Katherine K. Preston. Recent Researches in American Music 72. Music of the United States of America 23. Middleton, WI: A-R Editions, 2011.

—. "A Concentration of Talent on Our Musical Horizon': The 1853-54 Tour by Jullien's Extraordinary Orchestra." In American Orchestras in the Nineteenth Century, ed. John Spitzer, 319-47. Chicago: University of Chicago Press, 2012.

Ritterman, Janet. "Schumann and the English Critics: A Study in NineteenthCentury Musical Reception." In Musical Dimensions: A Festschrift for Doreen Bridges, ed. Martin Comte, 192-211. North Melbourne: Australian Scholarly Publishing, 2009.

Saloman, Ora Frishberg. "Presenting Berlioz's Music in New York, 1846-1890: Carl Bergmann, Theodore Thomas, Leopold Damrosch.” In European Music $\&$ Musicians in New York City, ed. John Graziano, 29-49. Eastman Studies in Music. Rochester, NY: University of Rochester Press, 2006.

Shadle, Douglas. "Music of a More Perfect Union: Symphonic Constructions of National Identity, 1840-1870." Ph.D. diss., University of North Carolina at Chapel Hill, 2010.

Sicherman, Barbara. "Ideologies and Practices of Reading." In A History of the Book in America, Volume 3: The Industrial Book, 1840-1880, ed. Scott E. Casper, Jeffrey D. Groves, Stephen W. Nissenbaum, and Michael Winship, 279-302. Chapel Hill: University of North Carolina Press, 2007.

Stevenson, Karen M. “The Music Criticism of Franz Brendel." Ph.D. diss., Northwestern University, 1994.

Temperley, Nicholas. Bound for America: Three British Composers. Music in American Life. Urbana: University of Illinois Press, 2003.

Upton, William T. William Henry Fry: American Journalist and Composer-Critic. New York: Thomas Y. Crowell Company, 1954.

Walker, Alan. Franz Liszt: The Weimar Years, 1848-1861. New York: Alfred A. Knopf, 1988.

Warner, Michael. The Letters of the Republic: Publication and the Public Sphere in Eighteenth-Century America. Cambridge, MA: Harvard University Press, 1990.

Williamson, John. "Progress, Modernity, and the Concept of an Avant-Garde." In The Cambridge History of Nineteenth-Century Music, ed. Jim Samson, 424-59. Cambridge: Cambridge University Press, 2002.

\section{Discography}

Fry, William Henry. Santa Claus Symphony. Royal Scottish National Orchestra. Naxos 8.559057. 